Svetislav Lj. Marković, dipl. maš. inž.

\section{REGENERACIJA ZUPČASTIH I OŽLEBLJENIH SPREGA}

U ovom tekstu dat je pregled postojećih metoda regeneracije zupčanika i ožlebljenih delova mašinskih elemenata. U prvom delu su dati uzroci i karakter eksploatacionih oštećenja, defektacija, metodi regeneracije i ojačanja zupčanika, a $u$ drugom delu metodi regeneracije ožlebljenih spojeva zavisno od vrste $i$ veličine njihovih oštećenja.
Na zupčanicima i ožlebljenim delovima mašinskih elemenata nastaju raznovrsna oštećenja (istrošenost radnih površina, mehanička oštećenja, deformacije oblika i dimenzija, prskotine, lomovi i sl.). Mnogi od oštećenih zupčanika i ožlebljenih spojeva mogu se uspešno i pouzdano regenerisati.

Pod regeneracijom pohabanih zupčanika i ožlebljenih delova mašinskih elemenata podrazumeva se takav redosled operacija čiji je cilj povratak izgubljenih pokazatelja radnih sposobnosti tih elemenata. Regeneracijom se moraju obezbediti nazivne mere i zahtevani kvalitet površina, kao i pravilan geometrijski oblik i očuvanje (ili čak poboljšanje) osnovnih eksploatacionih karakteristika materijala regenerisanog elementa. Da bi se sve to uspešno ostvarilo, neophodno je dobro poznavati uzroke koji izazivaju oštećenja, karakteristike nastalih oštećenja i njihove dimenzije, metode za utvrđivanje oštećenja, opremu za regeneraciju, osnovne tehnološke i fizičko-mehaničke karakteristike metalnih slojeva koji se nanose na oštećene površine, kao i druge parametre.

\section{Regeneracija zupčanika}

Zupčanici su mašinski elementi namenjeni za prenos kružnog kretanja. U mašinstvu imaju široku primenu. Od njihove otpornosti na habanje i čvrstoće zavise $u$ znatnoj meri vek trajanja i pouzdanost mašina i mehanizama. Zupčanici se izrađuju od mnogo različitih materijala, u raznim geometrijskim oblicima i dimenzijama, metodima izrade, rade $u$ različitim eksploatacionim režimima, pa je i regeneracija zupčanika kompleksna. Osnovnu masu zupčanika, koji se primenjuju u mašinskoj industriji, čine cilindrični zupčanici sa pravim zupcima (oko 80\%). Primena koničnih zupčanika svih tipova dostiže $12 \div 15$, a cilindričnih sa kosim zupcima $3 \div 5$. Pri tome na zupčanike sa modulom do $4 \mathrm{~mm}$ i prečnikom koji ne prelazi $300 \mathrm{~mm}$ otpada oko $90 \%$ celokupne proizvodnje.

Regeneracija zupčanika obuhvata otkrivanje njihovih oštećenja, uzroka i karaktera, primenu najracionalnijeg i najpouzdanijeg metoda regeneracije i metoda ojačanja radnih površina zubaca.

Uzroci $i$ karakter eksploatacionih oštećenja zupčanika

Osnovni vidovi razaranja i oštećenja, zavisno od uslova $u$ kojima rade zupčanici, njihovih konstruktivnih i tehnoloških parametara, mogu biti:

- lom zubaca,

- zamorno krunjenje radnih površina zubaca, 
- abrazivno habanje,

- zadiranje ili zajedanje,

- plastično deformisanje površinskih slojeva materijala,

- cštećenja čela zubaca.

Izučavanje osnovnih vidova i uzroka razaranja zupčanika pokazalo je da iz pogona mnogo češće ispadaju pogonski zupčanici nego gonjeni. Obično su u mašinama lomu izložena dva-tri para zupčanika, koji su i po proračunu »slabi članovi«.

Lom zubaca izaziva iznenadno narušavanje radne sposobnosti mehanizma i cele mašine. On najčešće nastaje usled stvaranja zamornih prskotina u korenu zupca pri radu prenosnika. Ti lomovi mogu biti izazvani: višestruko ponavljajućim (cikličnim) opterećenjima na savijanje i malobrojnim, ali značajnim po veličini, preopterećenjima udarnog ili statičkog karaktera. Lom se javlja u korenu zupca zbog malog radijusa zaobljenja noge zupca i riseva od reznog alata, što stvara povećanu koncentraciju napona. Pri tome nastale zamorne prskotine u početku se razvijaju upravno na zaobljenje, a zatim se rasprostiru po dubini i duž zupca. Lom zubaca u korenu nastaje $\mathrm{i}$ usled dejstva zaostalih napona zatezanja u zoni međuzublja, koji nastaju pri termičkoj ili hemijsko-termičkoj obradi. Često se lom zubaca u korenu objašnjava dubokim kaljenjem i, samim tim, slabom otpornošću na udar. Posmatranja pokazuju da kod dužih zubaca često ne nastaje lom celog zupca, već samo njegovog dela. Ako na zupčaniku sa takvim oštećenjem nisu oštećeni ostali zupci, on se može koristiti za ponovnu eksploataciju.

Lom zubaca može nastati zbog velikih statičkih preopterećenja u slučaju nedovoljne čvrstoće zubaca na savijanje ili usled dinamičkih opterećenja, pri kojima nastaje prekoračenje pokazatelja udarne viskoznosti materijala. Pri velikom habanju radnih površina zubaca u prenosniku nastaje porast dinamičkih opterećenja. Pored toga, usled sma- njenja njihove debljine dolazi do smanjenja čvrstoće zubaca, što može izazvati lom. Netačnost montaže i izrade zupčanika, a takođe i greške drugih elemenata u sklopu dovode do pojave koncentracije napona na krajevima zubaca, što pogoduje njihovom lomu. Lom i razaranje zupčanika mogu nastati pri gruboj obradi, čak i neradnih površina zubaca. $\mathrm{Na}$ primer, kao rezultat grube obrade čela zubaca zupčanika automobilskih menjača pri povećanom opterećenju pojavljuju se prskotine na mestima riseva od noža, usled koncentracije napona na tim mestima.

Jedan od najrasprostranjenijih vidova razaranja zupčanika je usled krunjenja radnih površina zubaca. Razlikuju se dve vrste krunjenja:

- ograničeno, ili početno, koje odgovara periodu razrađivanja zupčastog para i ograničeno je tim periodom,

- progresivno, koje postepeno raste i dovodi do razaranja radnih površina zubaca.

Ograničeno krunjenje radnih površina zubaca može nastati kod zupčanika izrađenih od mekih i viskoznih materijala. Ono je izazvano koncentracijom opterećenja na malim delovima radnih površina ili na njenim posebnim neravninama i obično se javlja u početnom periodu rada zupčastog prenosnika. Posle krunjenja ovih delova, kada se nastala opterećenja preraspodele i zahvate veliki deo radnih površina, proces se prekida. Ograničeno krunjenje praktično ne pokazuje bitan uticaj na vek trajanja zupčastog prenosnika.

Progresivno krunjenje može se odvijati u početnom periodu rada samo kod zupčanika čije radne površine imaju visoku tvrdoću. Kod zupčastih prenosnika izrađenih od tvrdih ili od mekih materijala progresivno krunjenje se može odvijati u toku celokupnog vremena rada. Krunjenje metala počinje na mestima najvećih kontaktnih napona i pojavljuje se usled zamora površinskog sloja zupca. Tanki površinski 
sloj, koji je podvrgnut neprekidnom otvrdnjavanju deformacijom, puca i osipa se. To osipanje je veličine glave čiode ili malo veće, a počinje ispod kinematskog kruga. Zatim je takvom dejstvu podvrgnut sledeći sloj. Razaranje se rasprostire u dubinu materijala i zahvata sve veći i veći deo radne površine zupca. Vremenom ovo osipanje zahvata celu površinu i razara je. Pri tome je narušena tačnost sprezanja, to jest zupčasti prenosnik počinje rad sa udarima, što na svoj način doprinosi ubrzanom krunjenju radne površine. Šema odvijanja progresivnog krunjenja viskoznih materijala razlikuje se od opisane. $\mathrm{Na}-$ stalo osipanje na površinama zubaca od viskoznih materijala, pri daljem radu prenosnika, srazmerno raste. Istovremeno se pojavljuje i razvija novo osipanje. Stvaranje i razvoj osipanja odigrava se sve dok kontaktni naponi na radnim površinama zubaca, neoštećenih krunjenjem, ne porastu do veličine koja prevazilazi granicu tečenja, ili neki drugi pokazatelj mehaničke čvrstoće materijala. Posle toga nastaje promena površine, njeno intenzivno habanje ili zadiranje. Razvoj procesa krunjenja posledica je zamora tankih slojeva (debljine $15 \div 25 \mu \mathrm{m})$ materijala radnih površina zubaca. Intenzitet krunjenja zavisi od zamorne čvrstoće materijala, podmazivanja, veličine i smera relativnog klizanja radnih površina zubaca, brzine obrtanja zupčanika, a takođe i od kvaliteta površinske obrade. Progresivnom krunjenju doprinosi smanjenje tvrdoće cementacionog sloja, koje nastaje kao posledica grešaka pri cementaciji (dekarbonizacija, to jest smanjenje količine ugljenika na površini - slabo zasićenje površinskog sloja) ili termičkoj obradi. Nedovoljna tvrdoća cementacionog sloja pogoduje pojavi površinske plastične deformacije i izvrtanju profila zupca. Pri tome dolazi do povećane sile trenja, što izaziva povećanje temperature kontaktnih površina i mogućnost otpuštanja površinskog sloja. Treba napomenuti da se u literaturi pro- gresivno zamorno krunjenje radnih površina zubaca često naziva piting.

Abrazivno habanje je izazvano prisustvom stranih tela, mineralnih ili metalnih čestica među dodirnim površinama. Takvo habanje dominira pri nedovoljnoj zaštiti prenosnika od prljanja i slaboj filtraciji ulja. Podmazivanje smanjuje abrazivno habanje, ali ga ne eliminiše. Ovo habanje se najčešće javlja $\mathrm{u}$ prenosnicima rudarskih mašina. Tu ono protiče velikim intenzitetom i u većini slučajeva je vodeće. Bez obzira na to što se materijal zupčastih prenosnika rudarskih mašina, kao po pravilu, podvrgava termičkoj obradi i poseduje visoku tvrdoću, zupčanici se najčešće remontuju usled prekomernog habanja radnih površina $\mathfrak{i}$ zupci se regenerišu. Abrazivno habanje radnih površina zubaca dovodi do slabljenja podnožja zubaca i deformisanja evolventnog profila.

Zadiranje nastaje zbog trenutnog prekida uljnog filma između radnih površina ili njegovog istiskivanja usled narušavanja režima podmazivanja. Prekid zaštitne sposobnosti uljnog filma izazvan je velikim lokalnim zagrevanjem i plastičnom deformacijom površinskog sloja. Suviše gusto sredstvo za podmazivanje može biti uzrok zadiranja. Trenutni metalni kontakti, koji nastaju pri prekidu uljnog filma, uglavnom su rezultat velikih opterećenja i velikih brzina. Kao posledica toga, pri uzajamnom klizanju materijala tvrdih površina nastaju brazde na mekšem materijalu. Zajedanje nastaje zbog velikog lokalnog zagrevanja kontaktnih površina. Karakteriše se velikim česticama materijala, koje se otkidaju od jedne površine $i$ »zavaruju « na drugu, što i određuje stepen oštećenja zubaca. Radi odstranjivanja zadiranja i zajedanja na radnim površinama zupčanika, koji se koriste u brzohodnim i prenosnicima srednje brzine, kao i teško opterećenim sporohodnim prenosnicima, primenjuju se ulja velikog viskoziteta sa dodatkom sumpora ili hlora. Ovi elementi sprečavaju zavarivanje čestica. 
Plastično deformisanje pojavljuje se na radnim površinama teško opterećenih zupčanika, izrađenih od mekih čelika. Tada dolazi do plastičnog pomeranja čestica materijala po radnoj površini jednog istog zupca. U takvom slučaju nastaje deformisanje (krivljenje) oblika zubaca. $\mathrm{Na}$ radnim površinama zubaca jednog zupčanika stvaraju se urezi (žlebovi), a po drugom - izbočine. Ovakva oštećenja zupčanika često nastaju pri puštanju u rad jako opterećenih vratila. Pri dužem radu, usled otvrdnjavanja deformacijom, povećavaju se mehanička svojstva materijala i smanjuje se plastično deformisanje. Da bi se izbeglo plastično deformisanje radnih površina zubaca vrši se uhodavanje zupčanika pod opterećenjem većim od radnog.

Uključivanje $i$ isključivanje zupčanika $\mathrm{u}$ aksijalnom smeru (na primer, kod menjača) obično dovodi do oštećenja čela zubaca. Pri prebacivanju zupčanika s jedne na drugu brzinu, čela zubaca udaraju jedna o druga. Posledica toga je postepeno krunjenje čeonih ivica. Grebanje čestica cementiranog sloja pri čeonim udarima zubaca olakšano je povećanom krtošću tog sloja i velikim zaostalim naponima, koji nastaju u vezi sa strukturnom heterogenošću zona cementacionog sloja. Nepotrebno zasićenje površine zubaca ugljenikom i oštro smanjenje njegove koncentracije po dubini sloja dovodi do pojave velike količine zaostalog austenita na površini. Tu pojavu prate zaostali naponi zatezanja. Pod uticajem otvrdnjavanja deformacijom, koje nastaje na čelima zubaca pri promeni brzine, zaostali austenit spoljašnje zone cementiranog sloja prelazi u martenzit. Ova pojava je praćena proširenjem jezgra i nastankom velikih unutrašnjih napona. Pri nedostatku visoke tvrdoće čela zubaca zapaža se njihovo habanje ili gnječenje, pri prekomerno visokoj tvrdoći - krto razaranje, koje vodi raspadanju čela zubaca. Pri mekom jezgru i tvrdoj površini čela zubaca nastaje probijanje površinskog sloja.
Postoji niz mera koje preduzimaju proizvođači, a koje su usmerene ka smanjenju habanja čela zubaca menjačkih zupčanika. Smanjenje ispadanja zupčanika iz pogona je postignuto:

- primenom racionalnog zaobljenja čela zubaca,

— poboljšanjem termičke obrade čela zubaca,

- primenom savremenih modela racionalnijih kočnih sistema u mašinama i mehanizmima.

Uzroci oštećenja zupčanika vezani su, s jedne strane, za netačnost podataka o opterećenjima koja deluju na prenosnik i, s druge strane, za odstupanje faktičke čvrstoće zubaca od proračunske, pod uticajem konstruktivnih, tehnoloških i eksploatacionih faktora, nedovoljno uzetih u obzir pri projektovanju. Dejstvo različitih uzroka pokazuje se u pojavi dopunskih sila, koncentraciji napona, nepovoljnom rasporedu zaostalih (unutrašnjih) napona, smanjenju mehaničkih svojstava materijala i slabljenju opasnog preseka zupca.

Mogu se navesti sledeći primeri konstruktivnih uzroka:

a) razlika karakteristika čvrstoće materijala korišćenih u proračunu, koje su dobijene standardnim ispitivanjem obrazaca, i odgovarajućih karakteristika realnih zupčanika;

b) odsustvo frikcione spojnice $\mathrm{u}$ lancu glavnog pogona, neracionalna konstrukcija i raspored sistema kočenja i druge konstruktivne greške koje dovode do velikih preopterećenja dinamičkog karaktera;

c) nepravilan izbor tolerancija i zazora projektovanog prenosnika, koji dovodi do dopunskih dinamičkih opterećenja na zupcima;

d) neujednačen raspored zupčanika u odnosu na oslonce, ne uzimanje u obzir deformacija vratila, ležajeva i tela zupčanika, određivanje suviše velike širine zupčastog venca pri relativno niskoj tačnosti izrade zupčanika, što u 
mnogim slučajevima dovodi do velike koncentracije napona na čeonim ivicama zubaca, i slično.

Primeri tehnoloških uzroka: poruke,

a) oštećenja materijala $u$ vreme is-

b) neracionalne šeme i režimi termičke obrade zupčanika,

c) greške mehaničke obrade: odstupanje pravca zubaca po dužini, greške u profilu, oštećenja površina zaobljenja i radnih površina zubaca, grubi tragovi obrade, postojanje prskotina, termička oštećenja nastala pri brušenju, povećanje mikroneravnina, smanjenje radijusa ivica i slično,

d) oštećenja u montaži: zakošenje, montiranje zupčanika sa neracionalnim zazorima u sprezi, postojanje nepotpunog sprezanja - po dužini zupca, nanošenje površinskih oštećenja pri montaži itd.

U eksploatacione uzroke spadaju:

a) nepravilno podmazivanje, neuredno filtriranje i zamena ulja, neispravnosti u sistemu podmazivanja (posebno kod rudarskih i poljoprivrednih mašina),

b) prekoračenje dozvoljenih režima rezanja (kod mašina alatki),

c) nepravilno upravljanje - oštro kočenje (kod transportnih uređaja, mašina alatki, građevinskih i drugih mašina),

d) preopterećenje, temperatura, vlaga i drugi uzorci.

Oštećenja zubaca nisu jedina oštećnja kod zupčanika. $\mathrm{Na}$ glavčinama zupčanika često se javlja habanje naležuće površine na vratilo, kao i ožlebljenog dela ili žleba za klin. Pored toga, na glavčini, paocima i obodu mogu se pojaviti prskotine, iskrivljenost, radijalno bacanje i slično.

\section{Određivanje tehničkog stanja \\ (defektacija) zupčanika}

Defektacija zupčanika sastoji se od vizuelnog posmatranja delova zupčani- ka i izvođenja posebnih tehničkih merenja. Pri defektaciji zupčanika posebna pažnja obraća se na stepen habanja, pravilnost oblika i tvrdoću radnih površina zubaca, proverava se da li postoje ubivotine, prskotine ili zadori na zupcima, obodu, glavčini i žlebovima.

Vizuelnim posmatranjem pažljivo se ispituju uglavnom zupci zupčanika, na kojima može biti otkriveno niz oštećenja (zadori metala, smicanje, plastično deformisanje, stvaranje jamica, krunjenje).

Habanje zupčanika dovodi do promene deblj.ine i oblika zubaca. Zato čak i pri konstantnoj ugaonoj brzini pogonskog zupčanika nastaju ubrzanja i usporenja gonjenog zupčanika. Promenljiva ugaona brzina zupčanika izaziva udarna opterećenja na zupcima, čija veličina zavisi od mase obrtnih elemenata, karaktera i veličine deformacije profila, obimne brzine i drugog. Ispitivanja su pokazala da veličina dopunskih opterećenja na zupcima, koja su izazvana deformacijom oblika usled habanja, može pri velikim brzinama porasti do trostrukih proračunskih opterećenja. Zbog toga se granično habanje zubaca zupčanika, kod kojih obimna brzina prelazi $3 \mathrm{~m} / \mathrm{s}$, usvaja od 3 do $10 \%$ debljine zupca merene po podeonom krugu. Manje vrednosti odgovaraju većim brzinama. Granično habanje čeličnih sporohodnih zupčanika $(\mathrm{v}<3 \mathrm{~m} / \mathrm{s})$ može biti od 10 do $25 \%$ debljine zupca, merene po tetivi podeonog kruga. Veličina habanja praktično se najčešće određuje merenjem debljine zubaca i mere preko zuba. Izmerena veličina upoređuje se sa dozvoljenom graničnom, pa se na osnovu toga određuje da li je zupčanik ispravan ili je za regeneraciju.

Krunjenje je najopasniji vid habanja zupčastih prenosnika. Uzrok krunjenja je zamor materijala koji se javlja usled niza uzroka, na primer, rad prenosnika sa uljem lošeg kvaliteta, rascentriranost prenosnika, slab kvalitet površina zubaca. Pri radu sa uljem slabog kvaliteta ili pri slabom kvalitetu 
površina zubaca nestaje uljnog filma između površina zubaca i stvara se polusuvi kontakt metala u sprezi. To prouzrokuje plastično deformisanje materijala, povećanje tvrdoće i gubitka plastičnih svojstava, što na kraju dovodi do mikroprskotina. Pri radu rascentriranih zupčastih prenosnika opterećenje ne prenosi cela dužina zupca, već samo deo. Usled toga prenosnik radi sa preopterećenjem, narušava se hidrodinamički režim podmazivanja i ponovo stvaraju uslovi za pojavu zamora. Ako se na površinama zubaca stvore mikroprskotine, $u$ njih ulazi ulje. U šupljinama mikroprskotina stvara se kapilarni pritisak u hiljadama atmosfera. Pod dejstvom tog pritiska, ujedinjenog sa statičkim i dinamičkim opterećenjima, materijal zubaca se razara. Opasnost od krunjenja povećava se time što $u$ većini slučajeva proces teče neprekidno do potpunog ispadanja prenosnika iz pogona. Samo odstranjivanje uzroka pojave krunjenja može ga zaustaviti. Krunjenje se lako otkriva, posebno pri posmatranju pomoću uveličavajućih lupa. Ispitivanjima je ustanovljeno da se krunjenje najčešće uočava u zoni kontakta, bliže nozi zupca. Znatno ređe ono nastaje u zoni podeonog kruga. Inače, proces krunjenja do potpunog razaranja radnih površina zubaca obično teče u dužem vremenskom intervalu ('stotine časova).

Radi određivanja dozvoljenog habanja zubaca zupčanika izvršena je analiza promene napona zatezanja na radnoj strani zupca, koja nastaje kao rezultat smanjenja njegovog opasnog preseka. Kod cementiranih, nitriranih i nitrocementiranih delova zupčanika, pri određivanju veličine habanja njihovih zubaca, potrebno je uzeti u obzir dubinu sloja ojačanja. Preporučuje se da maksimalno dozvoljena veličina habanja kod takvih zupčanika bude tolika da debljina sloja ojačanja na radnim površinama zubaca, koji ostaje posle habanja, ne bude manja od $0,2 \div 0,25 \mathrm{~mm}$.

Prema uputstvima za remont zupčanika, koji se nalaze u sklopu vojnih sredstava, regeneracija se preporučuje ukoliko je krunjenje površinskog sloja zubaca:

- za zupčanike sa modulom većim od $6 \mathrm{~mm}$, na površini bokova zubaca od $8 \mathrm{~mm}^{2}$, krunjenje manje od $1,5 \mathrm{~mm}^{2}$,

- za zupčanike sa modulom $4 \div 6$ $\mathrm{mm}$, na površini bokova zubaca od 5 $\mathrm{mm}^{2}$, krunjenje manje od $1,5 \mathrm{~mm}^{2}$.

Pri većem krunjenju površinskog sloja zubaca zupčanici se odbacuju.

Pre remonta zupčanika moraju biti tačno određena oštećenja zupčanika i ustanovljeni njihovi uzroci. Pored veličine krunjenja, provereni moraju biti zazori između zubaca zupčanika, koji se nalaze u sprezi, i pravilnost kontakta zubaca. Bočni i radijalni zazori se proveravaju postavljanjem olovne žice u te zazore i njenim valjanjem pri obrtanju zupčanika (slika 1). Veličina zazora određena je debljinom olovne pločice dobijene posle valjanja žice. Debljina ove spljoštene žice meri se mikrometrom.

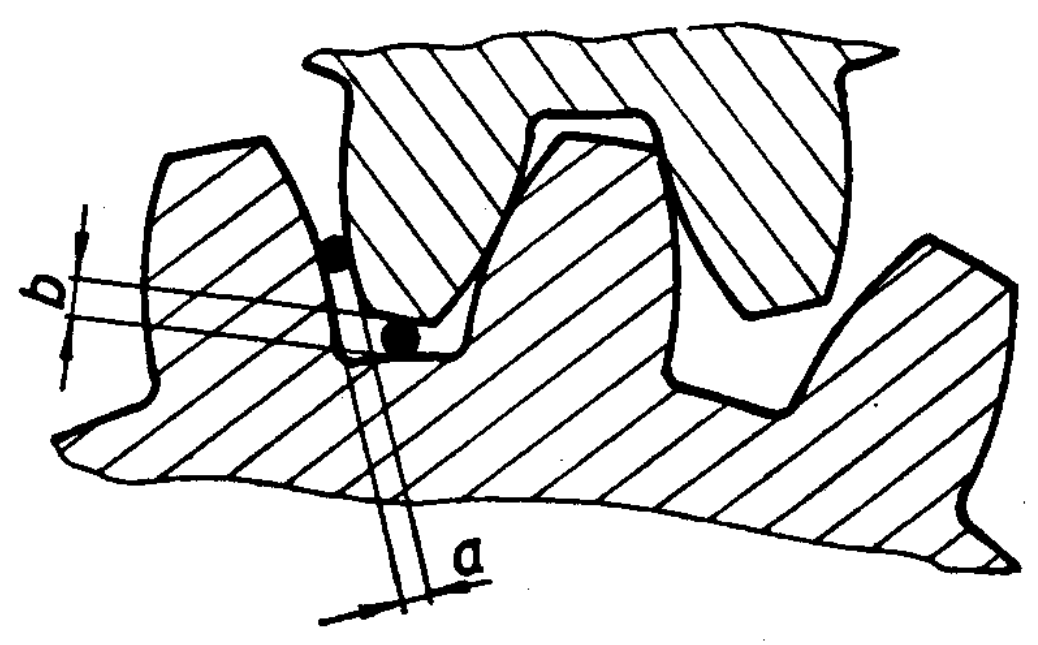

Sl. 1 - Provera zazora zupčastog prenosnika:

$a$ - bočni zazor, b - radijalni zazor

Bočni zazor između neradnih profila dva zupca u sprezi treba da bude od $t / 40$ do $t / 20$, zavisno od tačnosti obrade profila zubaca ( $t$ - korak ozubljenja). Radijalni zazor između glave zupca i međuzublja spregnutih zupčanika (cilindričnih i koničnih) je 0,2 modula sa maksimalnom tolerancijom $0,5 \div 0,8 \mathrm{~mm}$.

Bočni (uljni) zazor u sprezi može biti izmeren i indikatorom (slika 2). Pi- 
pak indikatora (2) oslanja se na polugu (1) čvrsto vezanu za osovinu jednog od zupčanika. Traženi zazor $(\varepsilon)$ određuje se zaokretanjem zupčanika (3) sa polugom (1), pri nepokretnom drugom zupčaniku, prvo u jednu, a zatim u drugu stranu. Sabiranjem pokazivanja indikatora određuje se veličina ukupnog bočnog zazora $(\varepsilon)$. Pri proračunu bočnog zazora neophodno je uzeti u obzir dužinu poluge (L).

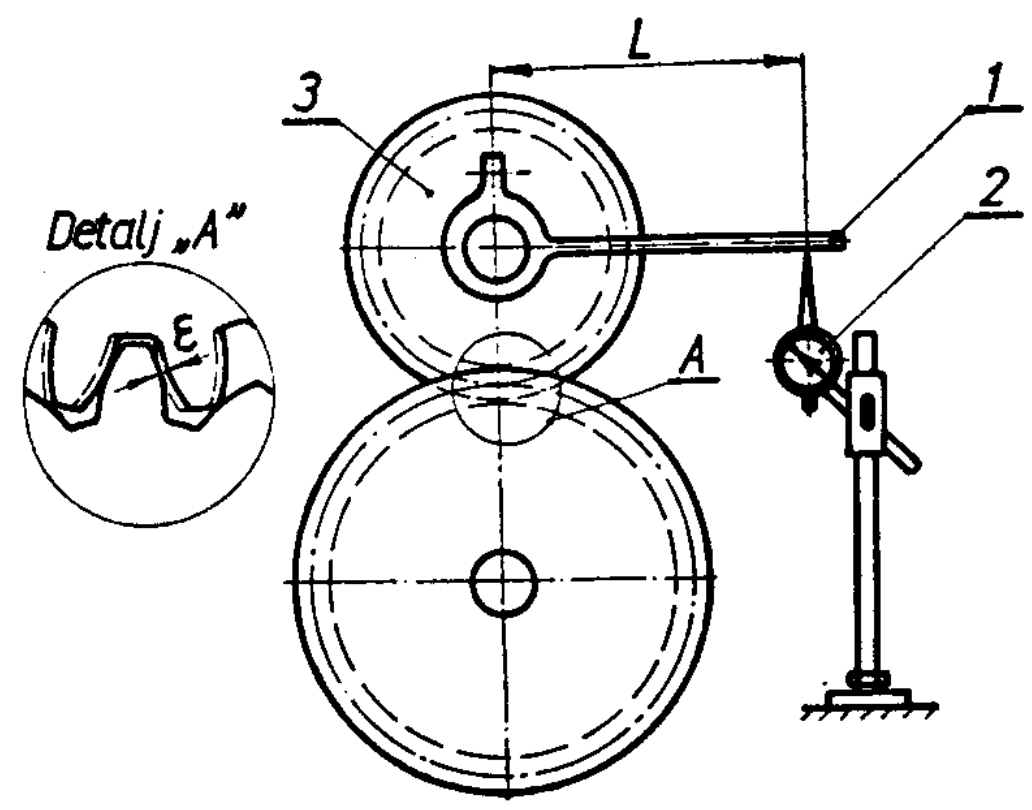

Sl. 2 - Merenje bočnog zazora u sprezi

Kvalitet centriranja zupčastog para može biti određen merenjem veličine neparalelnosti (slika 3) i zakošenja (sli-

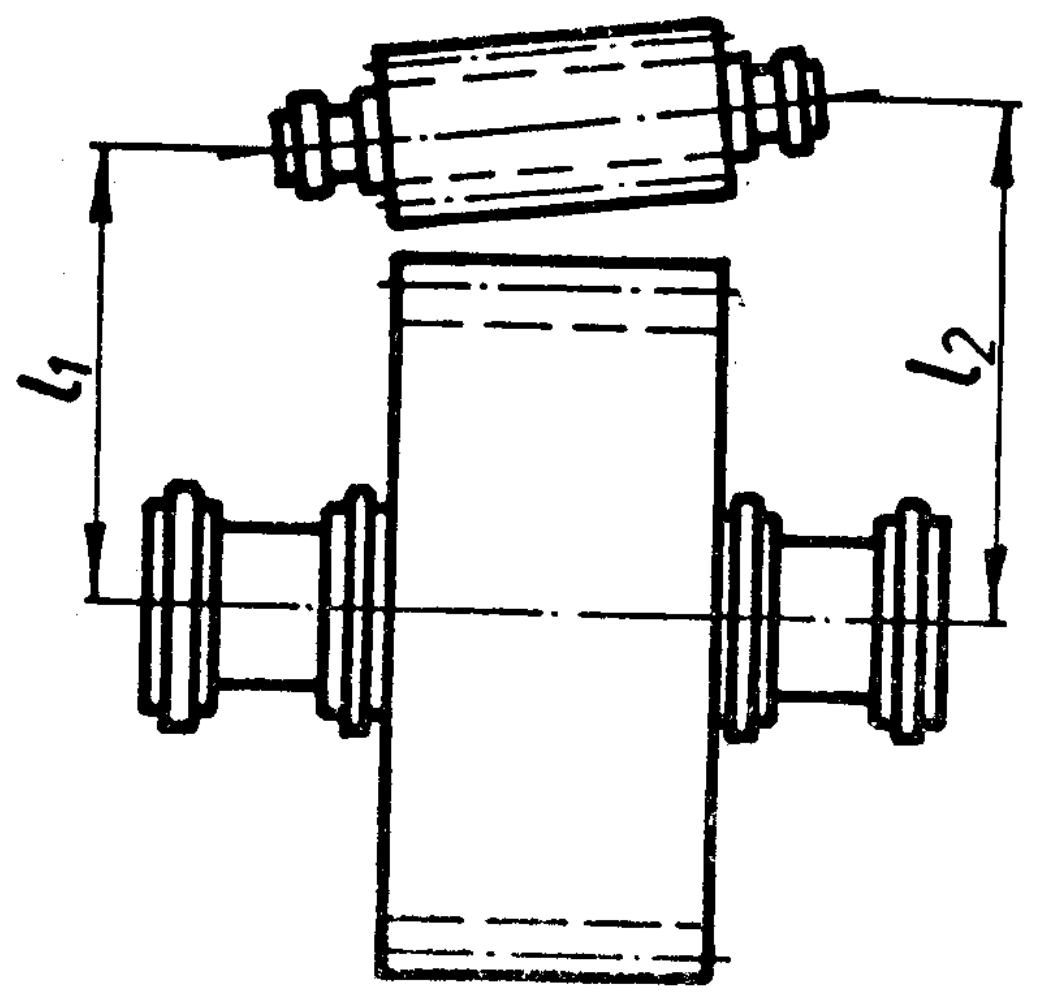

Sl. 3 - Neparalelnost osa zupčanika zupčastog prenosnika ka 4) osa zupčanika. Pod neparalelnošću osa podrazumeva se neparalelnost u ravni njihovog postavljanja. Neparalelnost se određuje nejednakošću međuosnog rastojanja $l_{1}$ i le.

Zakošenjem se smatra neparalelnost osa u ravni koja je upravna na liniju koja spaja centre zupčanika.

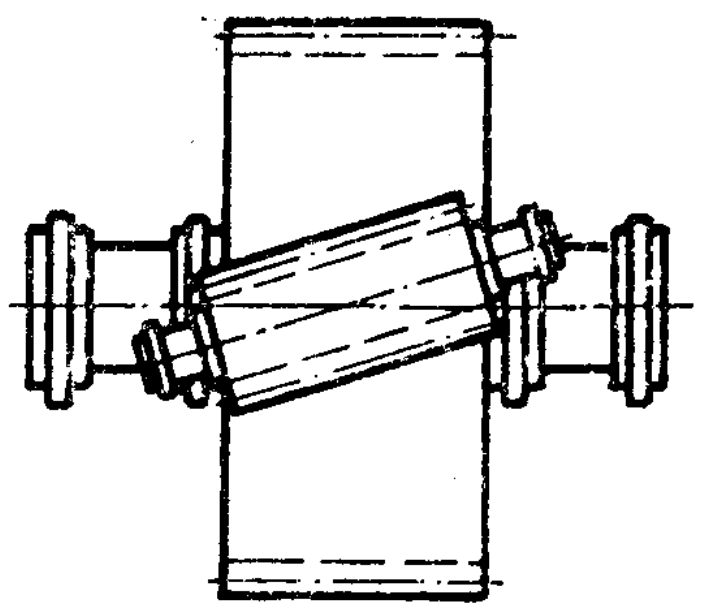

Sl. 4 - Zakošenje osa zupčanika zupčastog prenosnika

Ako se pretpostavi da postoji čista neparalelnost, onda će se zapaziti promena položaja zupca (1) u odnosu na međuzublje dva susedna zupca (2) duž dužine zupca, u ravni A (slika 5). Neka na dužini zupca postoji promena položaja glave zupca $\Delta h$. Istovremeno će se

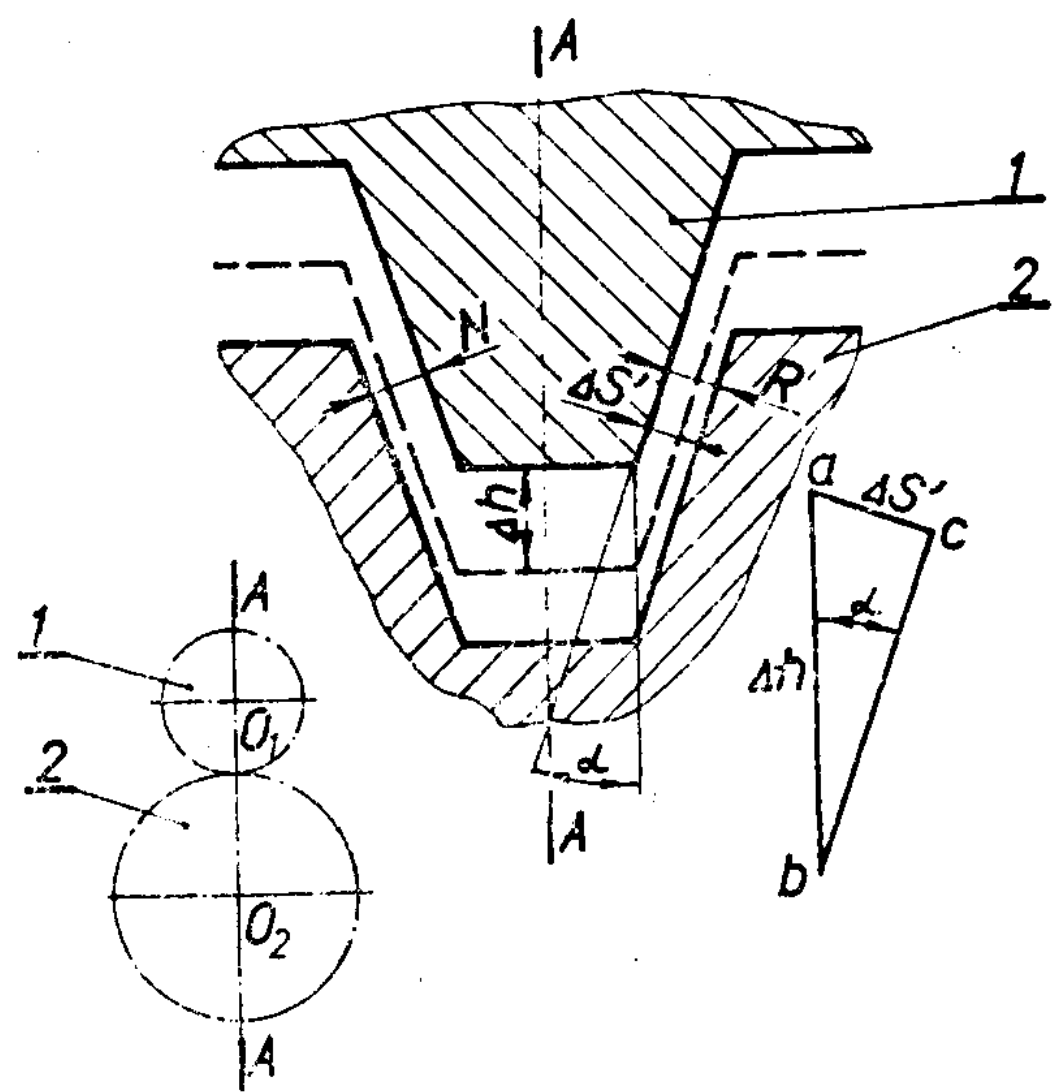

Sl. 5 - Položaj zupca u međuzublju pri neparalelnosti 
promeniti i veličina bočnih zazora $\mathrm{N}$ (neradnih) i R (radnih). Promenu jednog od njih duž dužine zupca (veličinu $\left.\Delta S^{\prime}\right)$ moguće je odrediti iz pravouglog trougla $(\mathrm{abc})$ :

$$
\Delta \mathrm{S}^{\prime}=\Delta \mathrm{h} \sin \alpha
$$

Veličina $\Delta \mathrm{h}$ može biti predstavljena kao nekakva specifična neparalelnost, izražena preko $X$ po jedinici dužine zupca l, obično za $1 \mathrm{~m}$. Na taj način izraz (1) moguće je napisati:

$$
\Delta \mathrm{S}^{\prime}=\mathrm{X} 1 \sin \alpha
$$

Kako se pri neparalelnosti menjaju i radni i neradni bočni zazori, ukupna promena bočnog zazora može se predstaviti formulom:

$$
\Delta \mathrm{S}_{1}=2 \quad \Delta \mathrm{S}^{\prime}=2 \times 1 \sin \alpha
$$

Otuda se specifična neparalelnost, ili neparalelnost na dužini zupca od 1 $\mathrm{m}$, nalazi prema izrazu:

$$
\mathrm{X}=\frac{\Delta \mathrm{S}_{1}}{21 \sin \alpha}
$$

Veličina ugla $\alpha$ zupčastih prenosnika je $20^{\circ}$, dužina zupca $l$ može biti izmerena neposredno. Na taj način, za određivanje veličine neparalelnosti po formuli (4) neophodno je samo merenje ukupnog bočnog zazora $\Delta \mathrm{S}_{1}$.

$\mathrm{Za}$ određivanje veličine zakošenja pribegava se analognom razmišljanju. Pretpostavimo da postoji čisto zakošenje. Iz trougla (mpq) (slika 6) nalazimo veličinu $\Delta \mathrm{S}^{\prime \prime}$ :

$$
\Delta \mathrm{S}^{\prime \prime}=\Delta \mathrm{K} \cos \alpha
$$

Veličina $\Delta \mathrm{K}$ može biti predstavljena kao proizvod neke tražene veličine specifičnog zakošenja $\mathrm{Y}$ i dužine zupca 1. Tada se, uzimajući u obzir promenu radnih i neradnih veličina bočnih zazora duž zupca, nalazi $\Delta \mathrm{S}_{2}$ :

$$
\Delta \mathrm{S}_{2}=2 \Delta \mathrm{S}^{\prime \prime}=2 \Delta \mathrm{K} \cos \alpha
$$

Pa je:

$$
\Delta \mathrm{K}=\frac{\Delta \mathrm{S}_{2}}{2 \cos \alpha}
$$

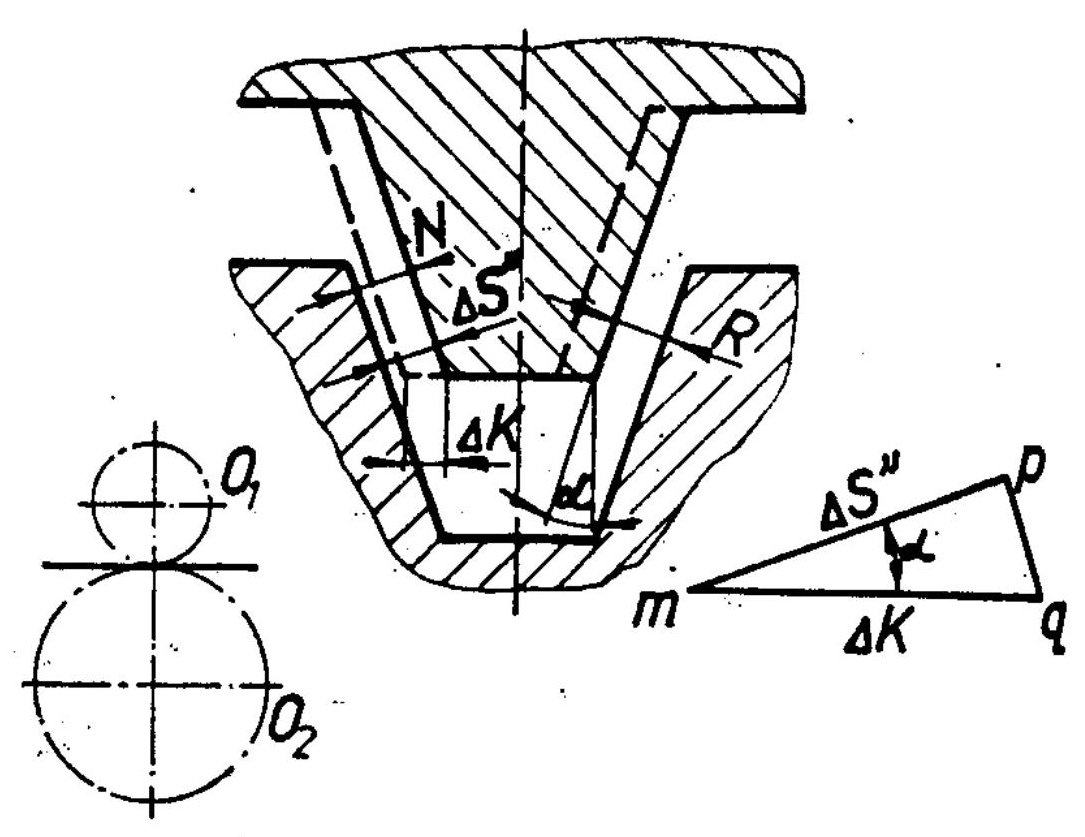

Sl. 6 - Položaj zupca u međuzublju pri zakošenju

Veličina $\Delta \mathrm{K}$ može biti predstavljena kao nekakvo specifično zakošenje $Y$ po jedinici dužine zupca l, koja obično iznosi $1 \mathrm{~m}$. Tada je:

$$
\Delta \mathrm{S} "=\mathrm{Y} l \cos \alpha
$$

Specifično zakošenje računa se po formuli:

$$
\mathrm{Y}=\frac{\Delta \mathrm{S}_{2}}{21 \cos \alpha}
$$

$U$ formulama (4) i (9) nepoznate veličine su $\Delta S_{1}$ i $\Delta S_{2}$. One se nalaze eksperimentalnim putem. Dve olovne žičice (1 i 2) dužina $150 \div 200 \mathrm{~mm}$ i prečnika oko $1 \mathrm{~mm}$ smeštene su između zubaca zupčastog para blizu njihovih čela (slika 7). Okretanjem zupčanika u jednom pa u drugom smeru dobija se olovni otisak, koji reprodukuje bočni zazor među zupcima. Pomoću mikrometra ili indikatora izmere se veličine radnih $\mathrm{i}$ neradnih zazora i nađu se njihove aritmetičke sredine. $\mathrm{Na}$ taj način se dobiju veličine:

$$
\begin{array}{ll}
\mathrm{R}_{1}=\frac{\stackrel{\mathrm{n} 1}{\Sigma} \mathrm{Ri}^{\prime}}{\mathrm{n} 1}, & \mathrm{~N}_{1}=\frac{\sum_{\mathrm{n} 2}^{\mathrm{n}} \mathrm{Ni}}{\mathrm{n} 2} \\
\mathrm{R}_{2}=\frac{\sum_{\mathrm{n} 3}^{\mathrm{n}} \mathrm{Ri},}{\mathrm{n} 3}, \quad \mathrm{~N}_{2}=\frac{\sum_{\mathrm{n} 4}^{\Sigma} \mathrm{Ni}{ }^{\prime \prime}}{\mathrm{n} 4}
\end{array}
$$


Ovde su $\mathrm{n}_{1}, \mathrm{n}_{2}, \mathrm{n}_{3}, \mathrm{n}_{4}-$ brojevi odgovarajućih merenja za svaku žičicu.
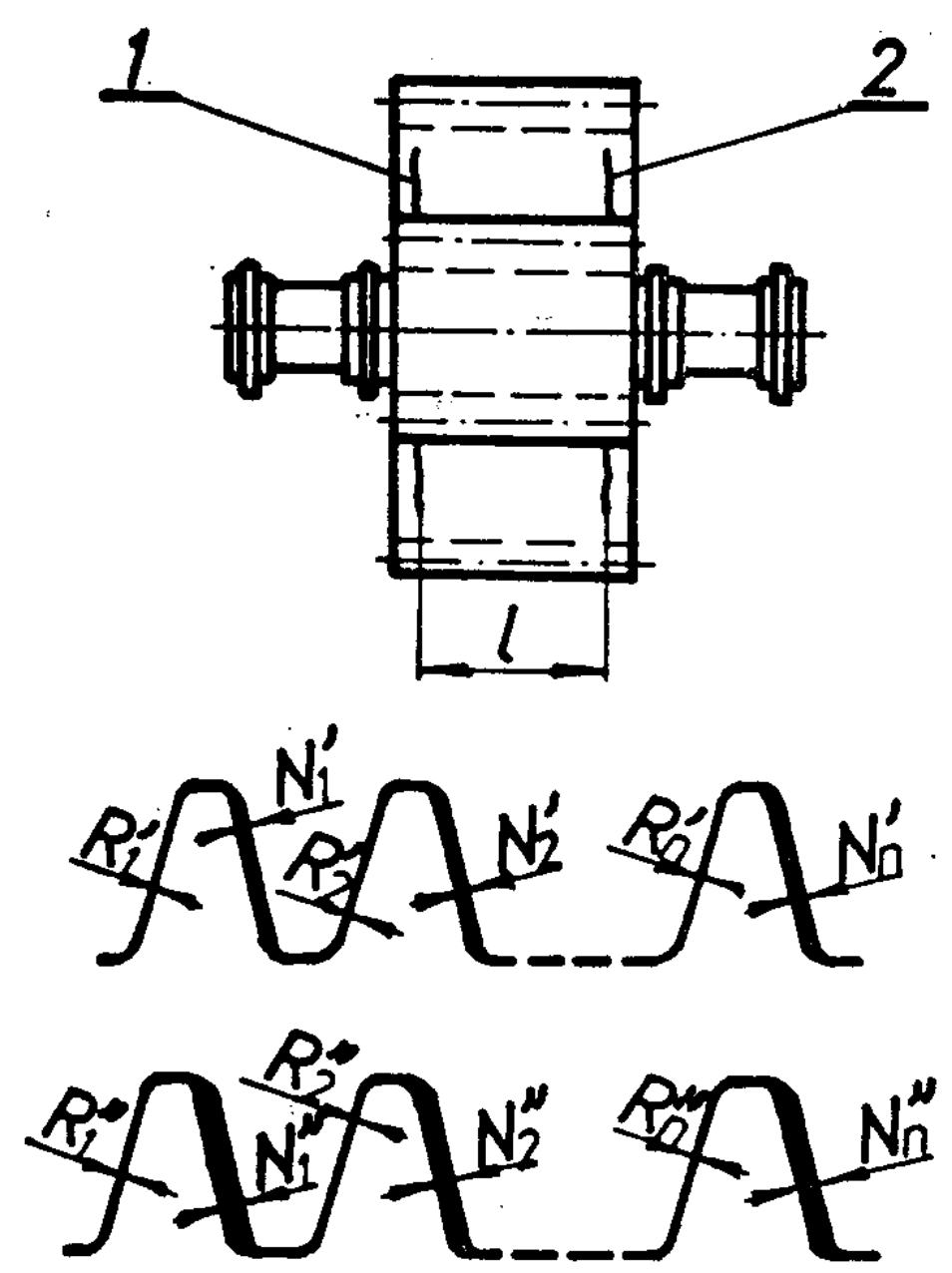

Sl. 7 - Provera kvaliteta centriranja zupčaste sprege pomoću olovnih otisaka

Nije teško primetiti da se veličina promene ukupnog bočnog zazora pri neparalelnosti duž zupca $\Delta \mathrm{S}_{\mathbf{1}}$ može izraziti veličinom:

$$
\Delta \mathrm{S}_{1}=\left(\mathrm{R}_{1}+\mathrm{N}_{1}\right)-\left(\mathrm{R}_{2}+\mathrm{N}_{2}\right)
$$

gde su $\left(R_{1}+N_{1}\right)$ i $\left(R_{2}+N_{2}\right)$ - ukupni bočni zazori na suprotnim krajevima zupca, tačnije na krajevima mere 1.

'Pri zakošenju, veličina $\Delta \mathbf{S}_{2}$ određuje se po formuli:

$$
\Delta S_{2}=\frac{\left(R_{1}-R_{2}\right)+\left(N_{1}-N_{2}\right)}{21 \cos \alpha}
$$

gde su $\left(\mathrm{R}_{1}-\mathrm{R}_{2}\right)$ i $\left(\mathrm{N}_{1}-\mathrm{N}_{2}\right)-$ promene radnog i neradnog bočnog zazora duž zupca na bazi mere 1 .

Postavljanjem nađenih veličina $\Delta S_{1}$ i $\Delta S_{2}$ u formule (4) i (9) dobijamo neparalelnost i zakošenje datog zupčastog para. Dobijene veličine upoređuju se sa graničnim tolerancijama. Tolerancije neparalelnosti i zakošenja kreću se od 0,05 do $0,1 \mathrm{~mm}$. Ponekad se zakošenje izražava u radijanima.

Kvalitet centriranja zupčastog para može biti ocenjen prema veličini kontakta u sprezi, to jest proverom traga kontakta. Pri ovom metodu radne površine zubaca jednog od spregnutih zupčanika premažu se ravnomernim slojem uljane boje. Posle kontakta na radnim površinama zubaca spregnutog zupčanika ostaje trag kontakta, koji omogućuje procenu radijalnog zazora i paralelnosti osa. Pri pravilnom sprezanju trag kontakta prostire se simetrično u odnosu na osu simetrije i liniju podeonog kruga zupčanika. Pri nepravilnom centriranju zupčanika karakter položaja traga kontakta pokazuje, u osnovi, grešku u montaži (tablica 1). Kontakt se smatra zadovoljavajućim ukoliko duž zupca on iznosi $80 \div 90 \%$ od njegove dužine i $40 \div 50 \%$ od njegove visine.

Pri nepravilnom sprezanju zupčasti prenosnik u radu stvara šum. Karakter šuma je pokazatelj vrste greške pri montaži prenosnika (tablica 1).

$\mathrm{Na}$ radnim površinama zupčanika, pužnih zupčanika i puževa, a takođe i na površinama zaobljenja noge zupca ne dozvoljava se pojava šupljina, čak ni ograničenih. $\mathrm{Na}$ neradnim površinama livenih zupčanika (obod, glavčina, paok) dozvoljene su male zasebne šupljine čija površina nije veća od $25 \mathrm{~mm}^{2}$, dubina od $3 \mathrm{~mm}$, a broj od 10 na $1000 \mathrm{~cm}^{2}$ površine. Zavarivanje prskotina na paocima i obodu livenih zupčanika se ne dopušta. Samo kod čeličnih zupčanika moguće je u nekim slučajevima zavariti prskotine oboda i paoka (ne više od tri, koje se ne prostiru jedna za drugom). Defektacija glavčine zupčanika, pored vizuelnog otkrivanja prskotina i drugih oštećenja, obuhvata i pregled merenjem otvora glavčine, žleba za klin ili ožlebljenog otvora glavčine. Preciznim mernim instrumentima meri se prečnik otvora, širina žleba za klin ili širina žlebova i prečnik ožlebljenog dela glavči- 
Tablica

PROCENA KVALITETA MONTAŽE ZUPČASTOG PARA

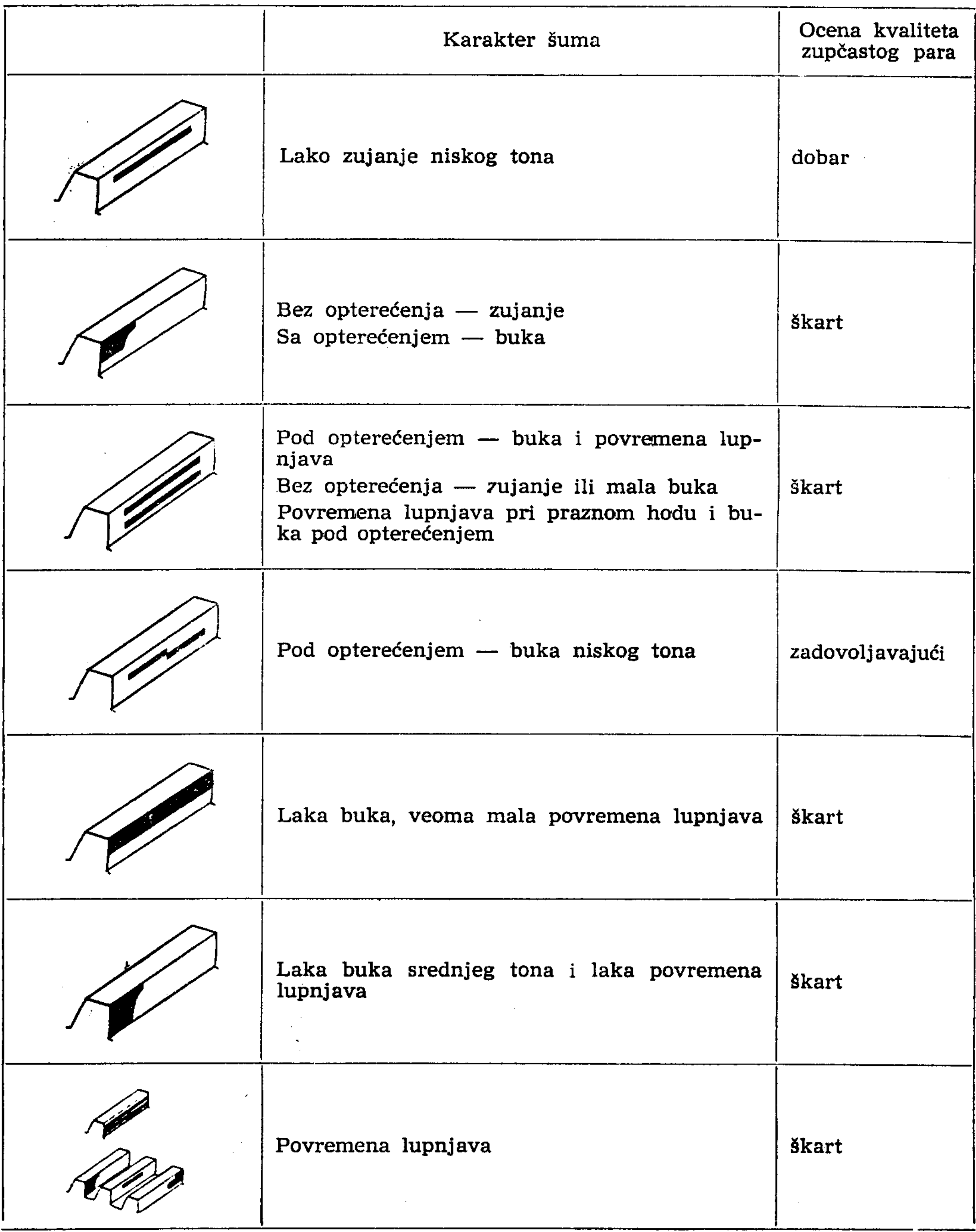


ne. Te mere se upoređuju sa dozvoljenim graničnim merama. Ukoliko je habanje veće od dopuštenog, glavčina se regeneriše.

Menjački zupčanici se podvrgavaju pregledu radi utvrđivanja nedozvoljenih nagnječenja i habanja čeonih površina zubaca. Dopušteno je nagnječenje i habanje čeone površine zubaca do dužine od $1 \mathrm{~mm}$ sa izlaskom na radnu površinu zupca površine manje od $5 \mathrm{~mm}^{2}$. Za razliku od zupčanika sa polomljenim i pohabanim radnim površinama zubaca, za zupčanike sa čeonim oštećenjima zubaca ne odgovaraju oštri kriterijumi za odbacivanje. Kao po pravilu, zamena zupčanika sa čeonim oštećenjima zubaca vremenski se podešava tekućem ili generalnom remontu. Najčešće razoreni deo zubaca zupčanika u momentu zamene je $15 \div 30 \%$ od prvobitne dužine zubaca (širine zupčastog venca). Ipak, sreću se slučajevi zamene zupčanika sa zupcima pohabanim samo za $10 \%$.

Provera krunjenja površinskog sloja, nagnječenja i habanja čeonih površina zubaca često se vrši komparativnim (uporednim) metodom sa etalon zupčanicima.

\section{Metodi regeneracije zupčanika}

Kod zupčanika habanju su najviše izloženi zupci, a zatim otvori, ožlebljeni otvori i žlebovi za klin na glavčinama. Uzroci regeneracije, takođe, mogu biti i prskotine u telu, glavčini $i$ vencu zupcanika. Prema tome, regeneracija zupčanika može se podeliti na: regeneraciju glavčine, regeneraciju tela i regeneraciju zubaca zupčanika.

$\mathrm{Na}$ glavčinama se habaju mesta sprezanja sa vratilima (naležuće površine). Tako oštećeni zupčanici regenerišu se elektrolučnim navarivanjem pohabane površine. Zatim se ta površina obrađuje na nominalne ili remontne mere (zavisno od stanja površine vratila na koju naleže). Regeneracija glavčine zupčanika navarivanjem racionalnija je od regeneracije, istim metodom, vratila na kojem se obrće zupčanik. Ova preporuka potvrđena je praktično i uslovljena je sledećim:

- stepen termičkog dejstva i pogoršanje strukture i mehaničkih karakteristika materijala glavčine zupčanika znatno je manje usled veće mase glavčine i zbog toga što se zupčanici, u većini slučajeva, izrađuju od niže ugljeničnih čelika u poređenju sa vratilima,

- vratila su podvrgnuta većim promenljivim naponima uvijanja i savinja, pri kojima je veoma opasno pogoršanje mehaničkih karakteristika površinskih slojeva materijala, koje izaziva navarivanje.

Pri regeneraciji pohabanih bočnih površina žlebova za klin potrebno je navariti jednu bočnu površinu žleba (slika 8). U tom slučaju jedna od radnih površina žleba, $i$ to ona koja nije podvrgnuta navarivanju, zadržava neizmenjenu strukturu i mehanička svojstva materijala. Zatim se vrši mehanička obrada, pri kojoj se dimenzije širine žleba očuvaju na račun sloja navarenog materijala, s jedne, i usecanja u osnovni materijal glavčine, s druge strane.

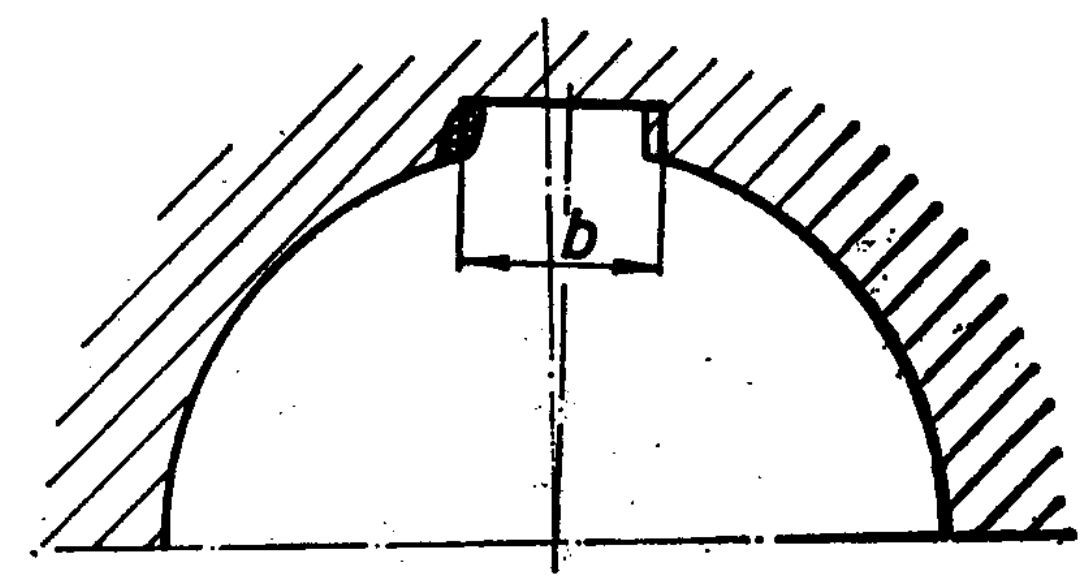

Sl. 8 - Regeneracija glavčine zupčanika sa pohabanim žlebom za klin

Regeneracija tela zupčanika najčešće se svodi na zavarivanje neprolaznih prskotina. Čelični zupčanici sa naprslim paocima, obodom i glavčinom regenerišu se zavarivanjem. Regeneracija paoka zavarivanjem dopuštena je ukoliko se naprsli paoci nalaze između celih. 
Pored toga, privremeno se može vršiti remont bravarskim metodom. Tada se obod steže čvrstom stegom ili spaja spojnicom sa vijcima. Zupčanici remontovani na ovakav način moraju u kratkom roku biti zamenjeni novim. Poželjno je zupčanike menjati u paru. Zamena jednog oštećenog zupčanika povlači brzo habanje novog. Nije dopušteno zavarivanje paoka i naprslih oboda livenih zupčanika.

Najodgovornija remontno-regeneracijska operacija jeste regeneracija zubaca zupčanika. Regeneracija zubaca zupčanika može biti hladnim - bravarskim metodima i vrućim navarivanjem.

Zupčanici sporohodnih prenosnika $(\mathrm{v}<2 \mathrm{~m} / \mathrm{s})$ regenerišu se hladnim metodima pomoću zavrtnjeva ili umetaka. Regeneracija primenom zavrtnjeva moguća je pri lomu pojedinih zubaca, ali ne više od dva uzastopna, kod zupčanika velikih modula. Deformisani zubac se odseče ili odrubi do osnove. Zatim se u telu zupčanika, na očišćenim površina-
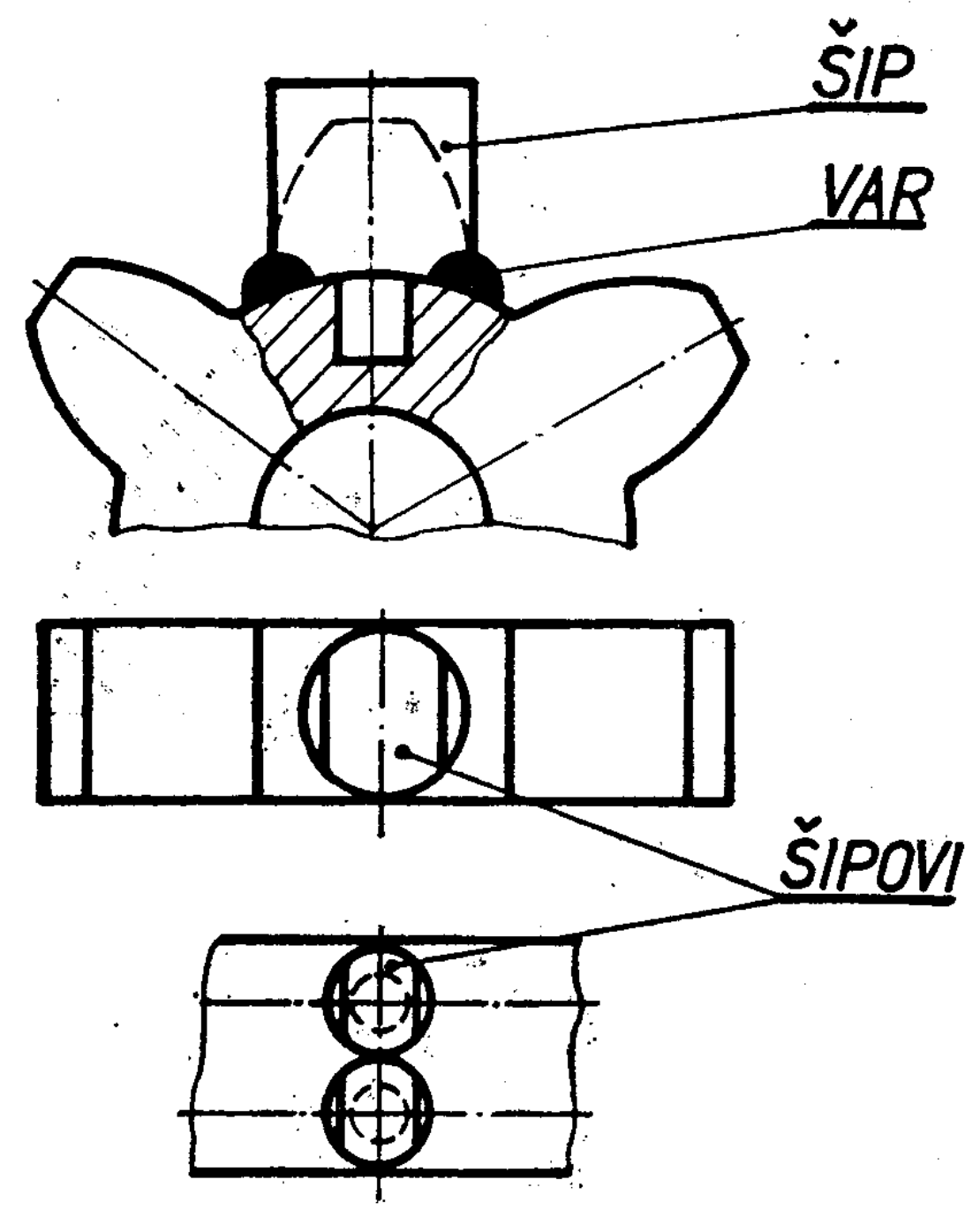

Sl. 9 - Regeneracija zubaca zupčanika uvrtanjem šipova ma, probuši nekoliko rupa, po celoj širini oboda, prečnika $0,5 \div 0,8$ od debljine zupca. Broj rupa zavisi od širine oboda. U te rupe urezuje se navoj, a u njega se uvrću čelični zavrtnji (šipovi), koji imaju prečnik jednak debljini zupca. Zavrtnji se zavare u osnovi i profil zupca se obrađuje na glodalici ili se turpijaju ručno - prema šablonu. Šema ovog metoda regeneracije zupca pomoću jednog i dva šipa prikazana je na slici 9.

Savršenija varijanta hladnog metoda regeneracije zubaca zupčanika sastoji se u sledećem (slika 10). Očišćeno mesto slomljenog zupca se otpušta. Susedni zupci, radi izbegavanja oštećenja pri otpuštanju, premazuju se mazivom $\mathrm{u}$ sastavu: $50 \%$ vatrootporna glina, $45 \%$ isitnjeni (meki) azbest i $5 \%$ vode-

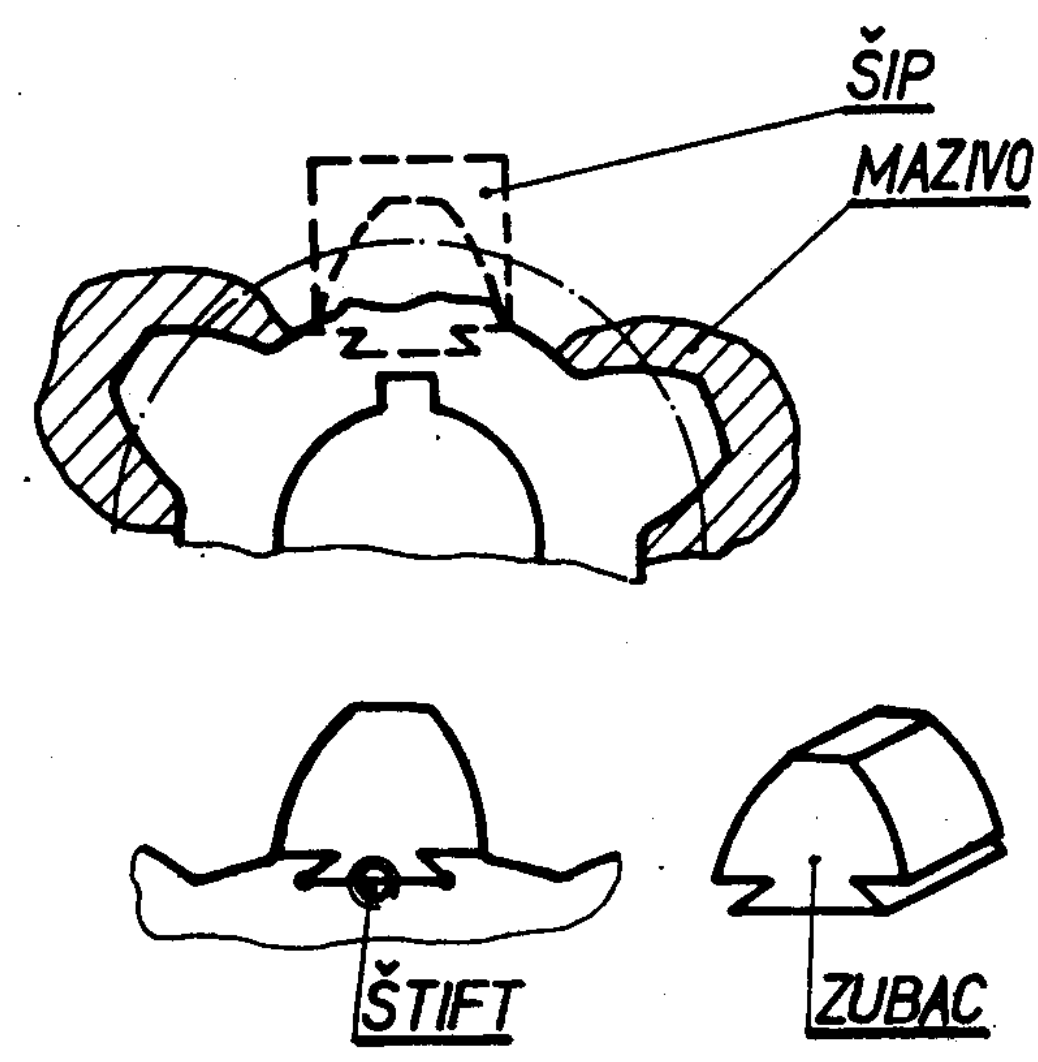

Sl. 10 - Regenetacija zubaca zupčanika postavljanjem šipa $u$ »lastin rep«

no staklo. Posle otpuštanja mazivo se udaljuje. Na mestu gde je bio zubac izvadi se žleb u obliku lastinog repa dubine $1 / 4 \div 1 / 3$ visine zupca. $U$ taj žleb se sa strane stavlja zubac, ili šip, ranije pripremljen, koji se učvršćuje navojnim štiftom, vijkom sa upuštenom glavom ili se sa čela osigura elektrolučnim 
zavarivanjem. Zatim se, ukoliko je potrebno, vrši obrada na tačan oblik zupca.

Ukoliko bušenje otvora za zavrtnje, ili urezivanje »lastinog repa«, slabi presek oboda zupčanika, preporučuje se regeneracija zupčanika primenom dodataka. Za postavljanje dodataka (slika 11) sa čela oboda se prave žlebovi dubine $0,4 \div 1,0$ modula. Širina žleba bira se na taj način da dodatak (1) zahvata sa svake strane po jedan neoštećeni zubac. Dodatak se postavlja $u$ žlebove i učvršćuje zavrtnjima (4). Krajevi dodatka se učvršćuju vijcima (2), koji se postavljaju ispod oboda zupčanika. Da bi se ograničilo savijanje krajeva dodatka, na vijke (2) se postavlja-

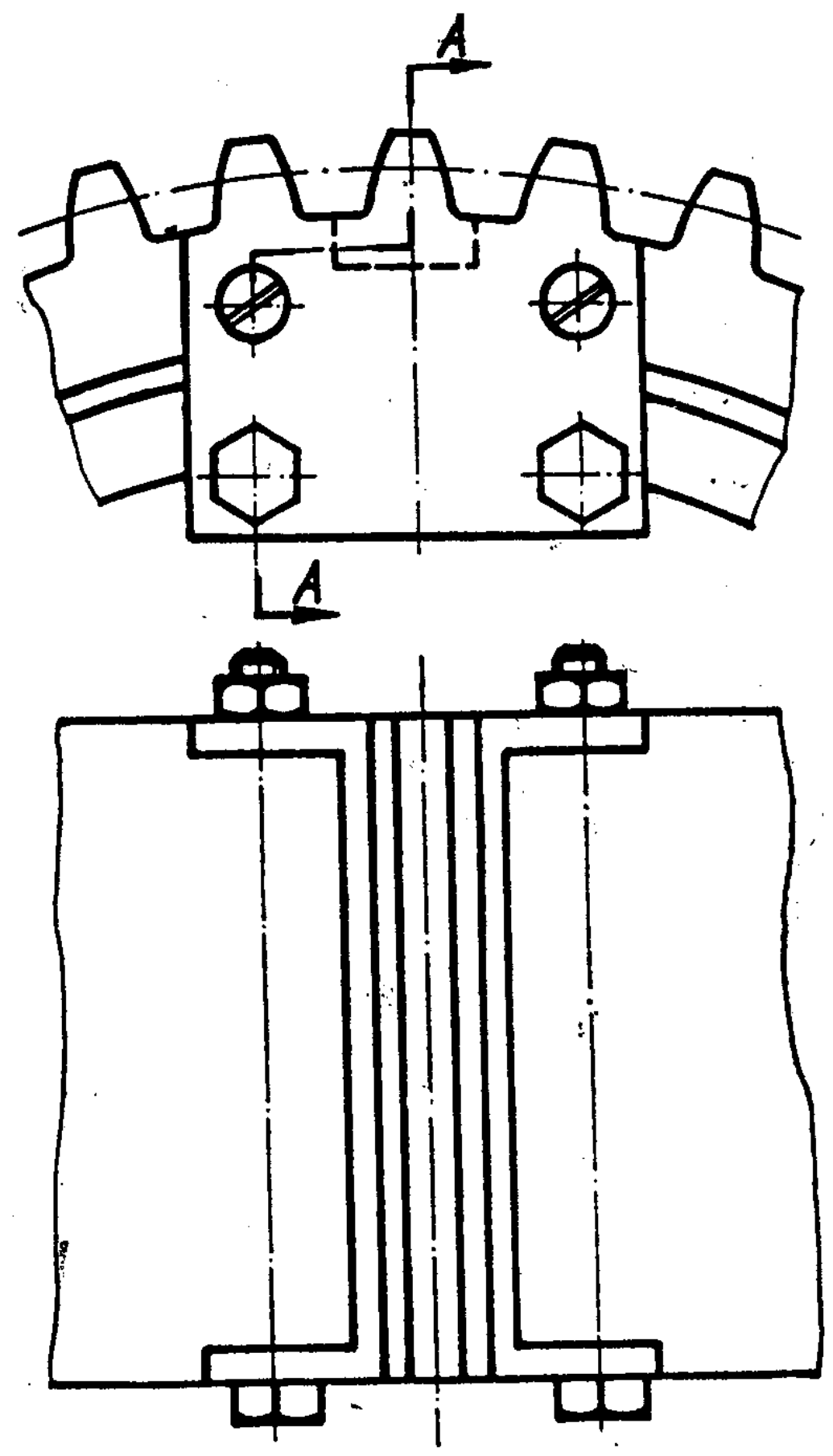

ju distantne čaure (3). Posle podešavanja dodatka zupci se obrađuju na običnim univerzalnim glodalicama.

Pri habanju (krunjenju) ili lomu nekoliko uzastopnih zubaca, regeneracija čeličnih zupčanika vrši se postavljanjem umetaka sa odgovarajućim brojem zubaca. Posle odrubljivanja ili odsecanja oštećenih zubaca, u obod se ukopa žleb dubine $1 / 4 \div 1 / 2$ visine zupca, u obliku lastinog repa. Zatim se u njega postavi umetak, izrađen od celika podudarnog materijalu zupčanika (slika 12). Umetak se učvršćuje na obodu, s boka, zavrtnjima ili elektrolučnim zavarivanjem (slika 12a). Pri velikoj dužini umetak se učvršćuje s čela zavrtnjima ili vijcima (slika 12b i c). Pre početka re-

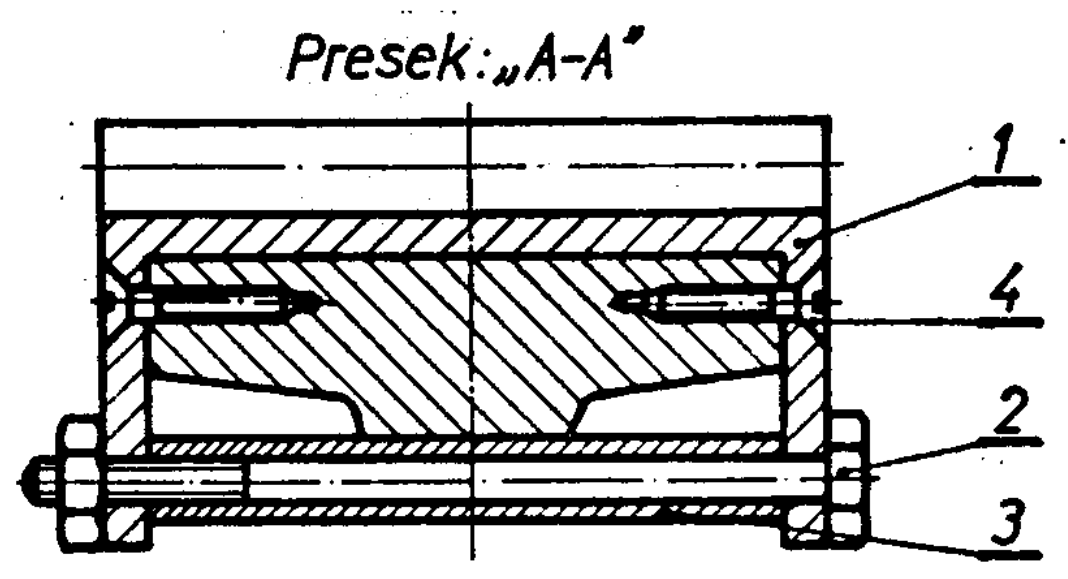

Sl. 11 - Regeneracija zubaca zupčanika po moću dodatka 
generacije obod zupčanika na mestu ukopavanja žleba treba otpustiti. Mesta koja ne podležu otpuštanju treba prekriti premazom.
Najsavremeniji način regeneracije oštećenih zubaca zupčanika jeste navarivanjem. Regeneracija dimenzija pohabanih zubaca čeličnih zupčanika vrši se

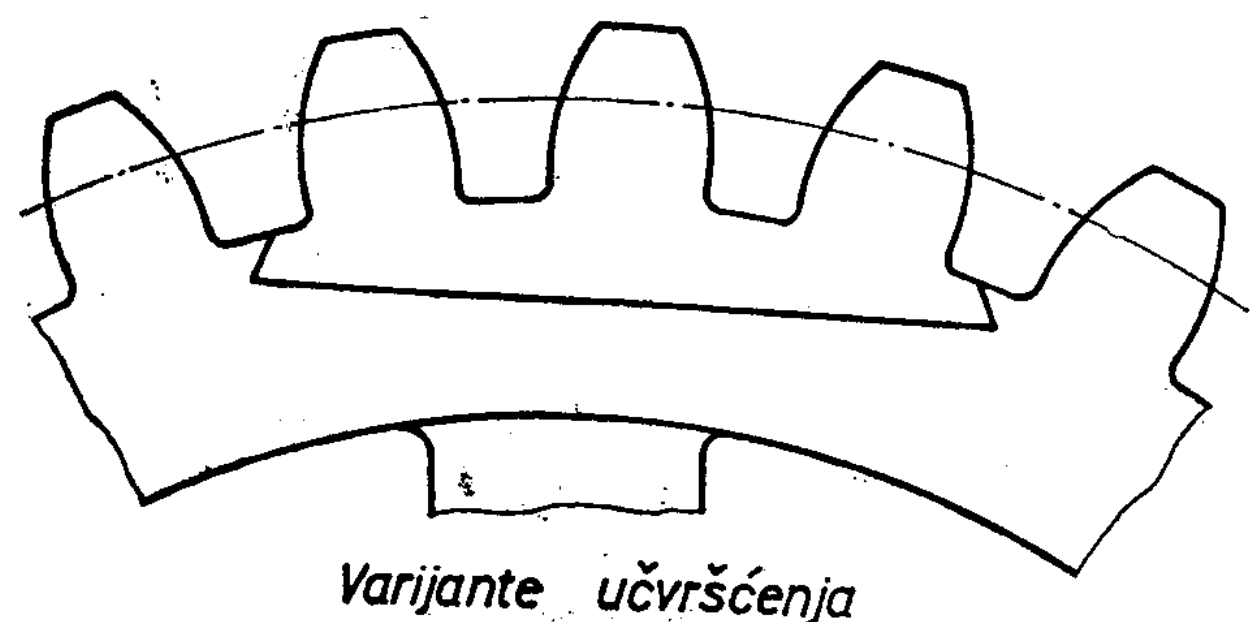

b)

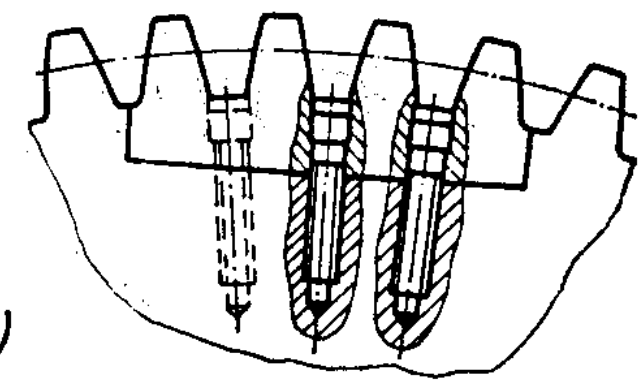

a)
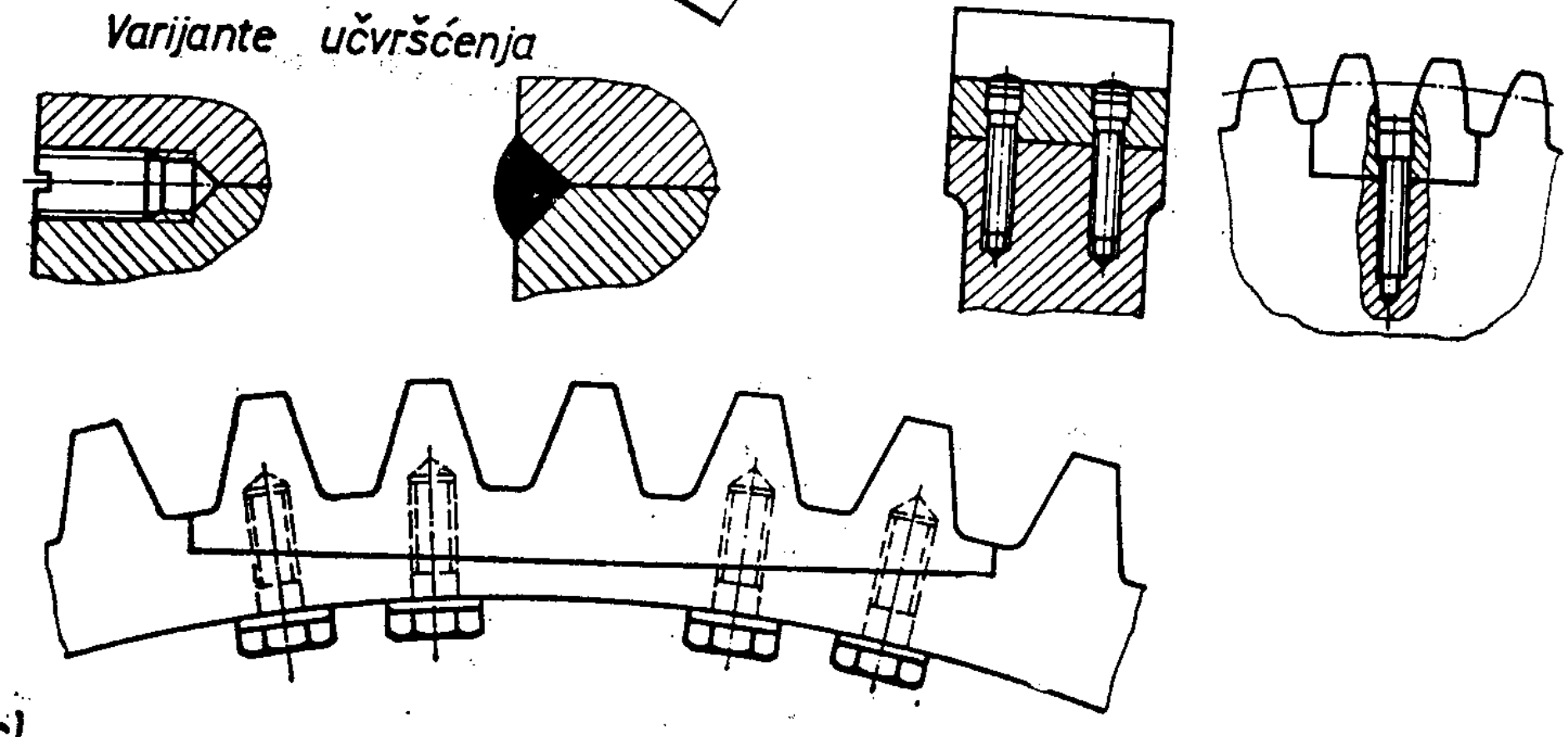

c)

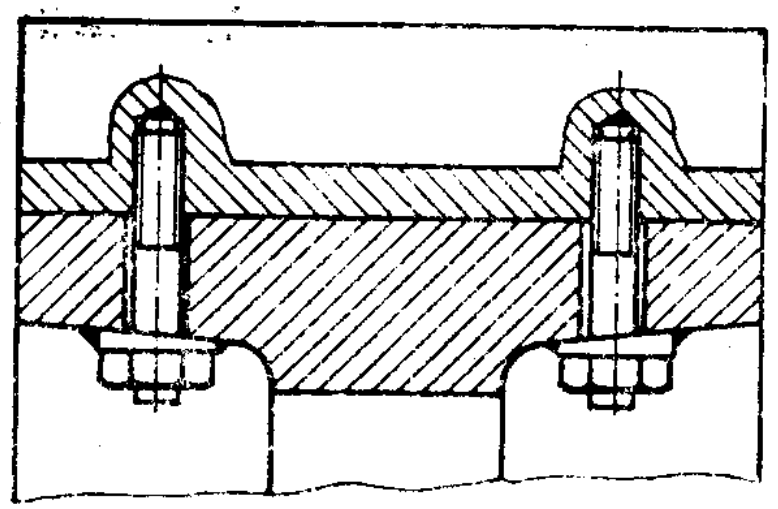

Sl. 12 - Metod regeneracije slomljenih zubaca zupčanika pomoću umetaka, koji su učvršćeni:

$a$ - s boka zavrtnjima ili zavarivanjem, b - odozgo zavrtnjima i c - odozdo vijcima

U poljskim uslovima, na sporohodnim prenosnicima izvodi se regeneracija zubaca zupčanika bravarskim metodom. To je uvrtanje šipova ili pričvršćivanje umetaka sa narezanim zupcima. Očigledno je da su to samo privremena rešenja. navarivanjem. Navarivanje može biti elektrolučno, ručno ili poluautomatsko, ili gasno, pomoću oksi-acetilenskog plamena. Elektrolučno navarivanje vrši se običnim zavarivačkim elektrodama ili specijalnim elektrodama za navarivanje sa debelom oblogom. Površina za nava- 
rivanje se prethodno pripremi čišćenjem čeličnom četkom do metalnog sjaja. Elektrolučno navarivanje vrši se pri jačini struje od 150 do $250 \mathrm{~A}$, u jednom sloju, čija debljina posle mehaničke obrade mora biti najmanje $1,5 \mathrm{~mm}$. U navarenom sloju neophodno je ostaviti mali dodatak za čišćenje i obradu navarenog zupca. Oblik zupca se kontroliše šablonom. Pri navarivanju zubaca malih modula (do $5 \div 6 \mathrm{~mm}$ ) ceo zupčanik se neprekidno zagreva toplom vodom.

Da bi se izbeglo bacanje zupčanika, navarivanje zubaca se ne vrši uzastopno (jedan za drugim), već svaki $5 \div 10$ zubac. Radi izbegavanja bacanja (vitoperenja), zupčanik se potopi u vodu tako da nepotopljeno ostane samo mesto koje se navaruje. Ono se prekrije azbestnom trakom sa prorezom za navarivanje. Pored toga moguće je zagrevanje zupčanika do $200 \div 260^{\circ} \mathrm{C}$. Posle navarivanja zupčanik se otpušta, zatim se vrši mehanička i termička obrada. Mehanička obrada se vrši na glodalicama ili rendisaljkama za izradu zupčanika. U nekim slučajevima, kada se ne zahteva velika tačnost, moguća je ručna obrada zubaca, turpijanjem ili ručnim električnim brusilicama.

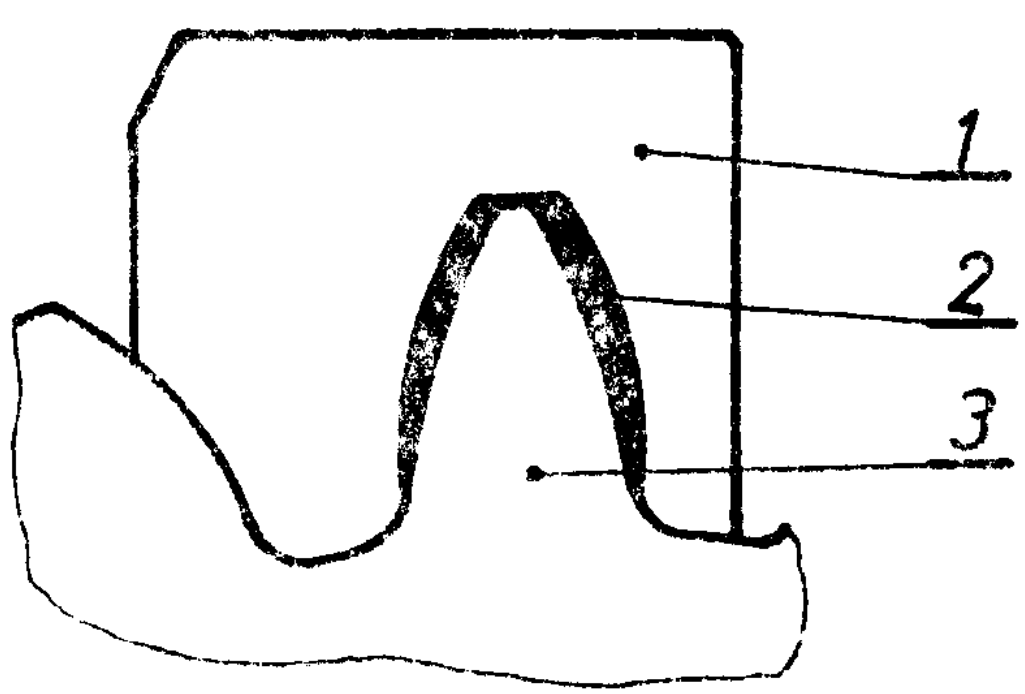

Sl. 13 - Sema navarivanja zubaca zupčanika pomoću šablona:

1-šablon, 2 - navareni sloj, 3 - regenerisani zupčanik

Za zupčanike sa malim modulom $(\mathrm{m}<5 \mathrm{~mm})$ navarivanje posebnih zubaca zamenjuje se potpunim navarivanjem zupčastog venca, koje se vrši po celom njegovom obimu. Zatim se na njemu narezuju zupci.

Pri regeneraciji zupčanika velikih modula poželjno je navariti zupce pomoću šablona, izrađenog od bakra ili mesinga (slika 13). Sablon sa regenerisanim zupcem obrazuje zatvorenu zapreminu koja se popunjava rastopljenim metalom. Da bi se zadržao korak između zubaca, šablon mora imati oslanjanje na susedni zubac.

Ako je zupčanik ranije bio termički obrađen (kaljen), neophodno je kaliti i nove zupce. Oni se zagrevaju gasnim gorionikom do $750 \div 820^{\circ} \mathrm{C}$. Susedni zupci moraju pri tome biti premazani zaštitnim mazivom. Posle zagrevanja zupci se brzo hlade vodom i čiste abrazivnim tocilom.

Zupčanici regenerisani navarivanjem otpuštaju se, mehanički obrađuju i termički dovode tvrdoću radnih površina zubaca do normi datih na crtežima ili u tehničkim uputstvima. Tvrdoća mora biti, za zupčanike izrađene od ugljeničnih čelika običnog kvaliteta (č. 0545, č. 0645) prosečno HRC $30 \div 45$, a za zupčanike od kvalitetnih čelika HRC $45 \div 65$. Regenerisane zupčanike, koji rade sa jednosmernim opterećenjem, svrsishodno je, ukoliko postoji mogućnost, montirati u mehanizme sa zaokretanjem za $180^{\circ}$. Tako bi se postiglo da regenerisane površine budu neradne, a površine zubaca sa nepromenjenom strukturom - radne.

Pri regeneraciji zupčanika izrađenog izjedna sa vratilom može biti primenjen metod regeneracije dela mašinskog elementa. Tada se na pripremljeno (struganjem, glodanjem i sl.) telo zupčanika (ili, bolje reći, vratilo) navuče polufabrikat ili novoizrađeni zupčasti venac u hladnom ili zagrejanom stanju. Taj polufabrikat zavaruje se po celoj čeonoj površini za telo zupčanika. Dalje se obrađuje na zahtevane dimenzije i vrši narezivanje zubaca. Pri tome se pre regeneracije termički obrađeni zupčanici otpuštaju, radi olakšanja mehaničke 
obrade. Posle presovanja, mehaničke obrade i narezivanja zubaca ponovo se kale.

Rotiranje mnogih sklopova vrši se pomoću cilindričnog zupčanika, spregnutog sa zupčastim vencem. Obično su to zupčasti venci velikih modula i velikih dimenzija. Primer za to je kupola na tenku. Ovakva sprega može raditi do habanja od $20 \%$ od prvobitne debljine zupca. Kada se habanje približi graničnom, elementi se šalju na regeneraciju navarivanjem. Da bi se izbeglo bacanje (vitoperenje) venca, treba ga zagrejati do temperature $250 \div 300^{\circ} \mathrm{C}$, a posle navarivanja lagano hladiti. Umesto zagrevanja moguće je venac potopiti u kadu sa vodom, tako da iznad njene površine ostane nekoliko zubaca. Posle navarivanja jedne grupe zubaca, venac se zaokreće $u$ vodi i nastavlja navarivanje. Gornji sloj zubaca svrsishodno je navariti tvrdim legurama ili uvesti u topitelj elemente koji obrazuju karbide hrom, molibden, volfram, titan. Posle nav́arivanja venac se proverava i ako je potrebno obrađuje na čeonom ili vertikalnom strugu i profil zubaca koriguje na mašini za obradu ozubljenja. Profil zubaca, navarenih tvrdim legurama, obrusi se abrazivnim tocilima, koja se dovode $u$ pogon od elektromotora preko savitljivog vratila. Oblik zubaca proverava se prema šablonu.

Kada zupčasti venac ostaje u pogonu sa habanjem zubaca od $20 \%$, s njim spregnuti zupčanik mehanizma za obrtanje svrsishodno je obraditi tako da profil zubaca odgovara povećanom međuzublju zupčastog venca.

Zupčaste letve se regenerišu navarivanjem pohabanih radnih površina zubaca i oslonih klizača (slika 14). Za navarivanje zupčastih letvi primenjuju se iste elektrode kao i pri navarivanju zubaca zupčanika. Posle navarivanja potrebna je obrada oslonih klizača na glodalicama ili brušenje tocilom. Navareni zupci se proveravaju šablonom.
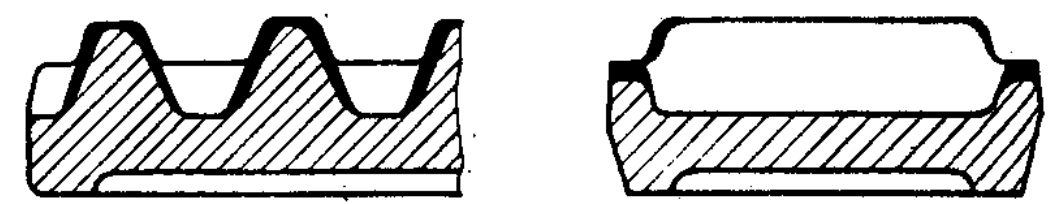

Sl. 14 - Regeneracija zupčaste letve navarivanjem

Ukoliko konstrukcija prenosnika to dozvoljava, pohabani zupci zupčanika mogu se regenerisati naknadnim korigovanjem. Korigovanje se vrši na račun smanjenja prečnika $i$, samim tim, međuosnog rastojanja.

\section{Metodi ojačanja zupčanika}

Za većinu zupčanika, a posebno za zupčanike koji prenose veliku snagu modula $\mathrm{m}=2,5 \div 6 \mathrm{~mm}$, primenjuje se površinsko ojačanje zubaca. To ojačanje može biti: termičko (indukciono kaljenje) i hemijsko-termičko (cementacija sa kaljenjem i nitriranje). Normalizacija, žarenje i poboljšanje svuda se koriste za prethodnu termičku obradu zupčanika, koji se podvrgavaju površinskom ojačanju. Ove operacije izvode se radi povećanja mehaničkih karakteristika materijala zubaca i smanjenja velikih unutrašnjih napona.

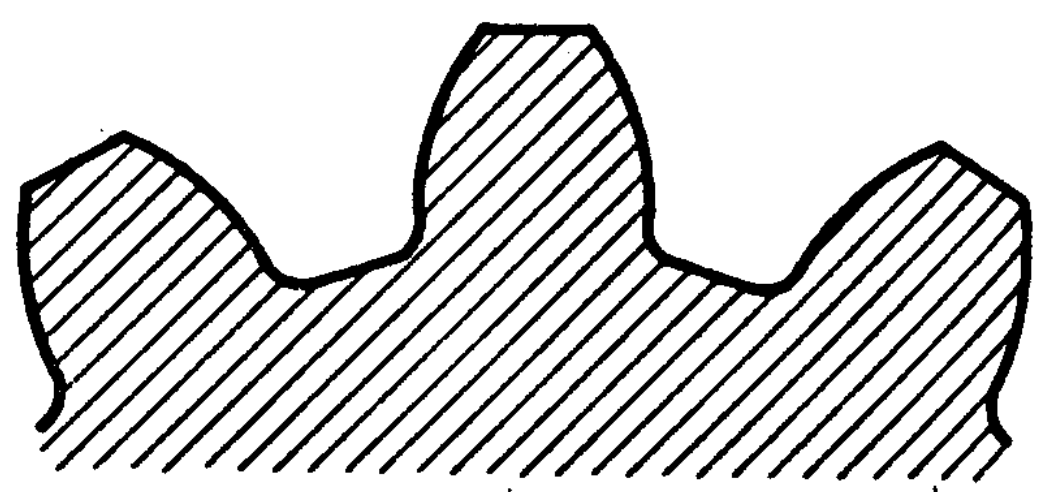

Sl. 15 - Raspored zona ojačanja pri zapreminskom kaljenju

Zapreminsko kaljenje (u pećima ili u kadi sa rastvorom soli) primenjuje se za zupčanike koji su prošli cementaciju ili nitrocementaciju. Zapreminsko ojačanje koristi se veoma retko, kao po pravilu, za slabo opterećene zupčanike 
malih i velikih modula. Pri ovom metodu ojačana je cela zapremina zupčanika, kao što je prikazano na slici 15 .

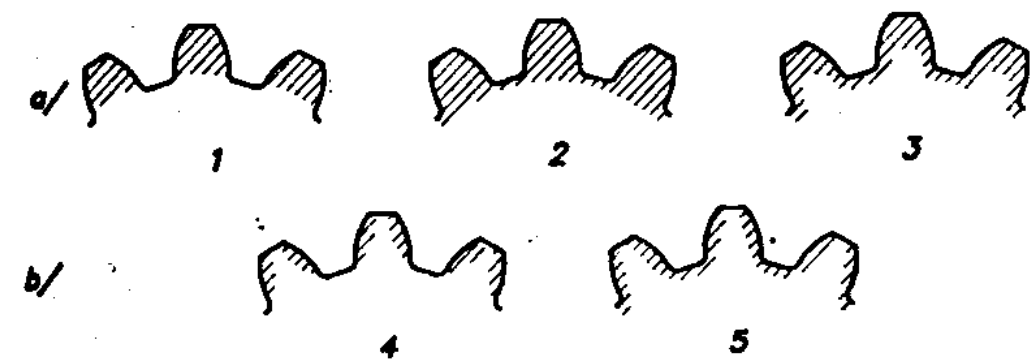

Sl. 16 - Raspored zona ojačanja pri indukcionom kaljenju:

$a$ - prodorno kaljenje $u$ prstenastom induktoru (jednovremeno), $b$ - površinsko kaljenje $u$ specijalnim induktorima (sukcesivno); 1 - nepotpuno, 2 - sa zahvatanjem dna meduzublja, 3 - čelik smanjene prokaljivosti, 4 - kaljenje radnih površina, 5-konturno kaljenje

Indukciono kaljenje pri zagrevanju visokofrekventnim strujama se deli: po šemi zagrevanja zubaca u toku vremena (jednovremeno i sukcesivno) i prema karakteru rasporeda okaljenih zona $u$ telu zupca (prodorno - nepotpuno i sa zahvatanjem dna međuzublja, konturno i po radnim površinama). Na slici 16 prikazane su različite varijante rasporeda zona ojačanja. Najprimenjeniji način je

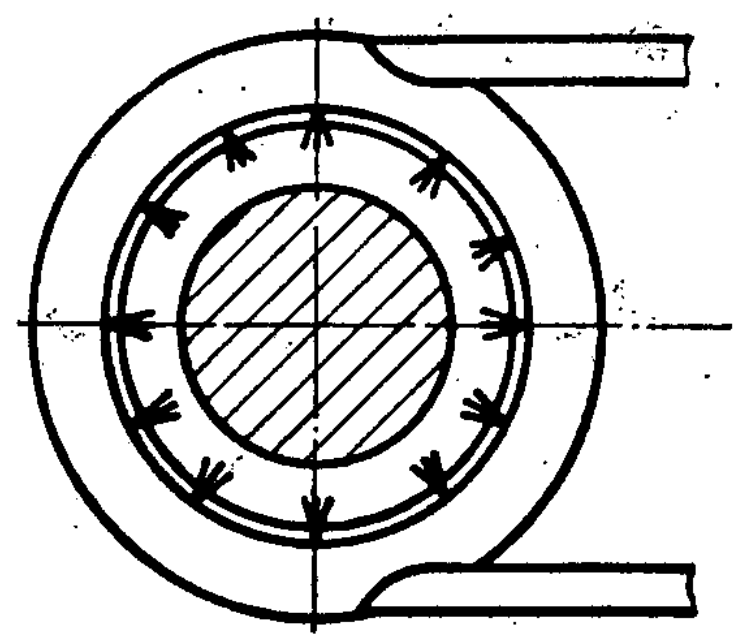

Sl. 17 - Šma indukcionog kaljenja sa prstenastim induktorom

jednovremeno kaljenje zupčastog venca sa prstenastim induktorom (slika 17), pogotovu za zupčanike sa modulom do $6 \mathrm{~mm}$. Prednosti su: visoka produktivnost, male teškoće $u$ radu, obezbeđenje zadovoljavajuce otpornosti na habanje i kontaktne čvrstoće zubaca. Zahtevana savojna čvrstoća noge zubaca ne dostiže se skoro nikada.

Sukcesivno kaljenje svakog zupca po radnim površinama, zagrevanjem u specijalnom induktoru (slika 18), primenjuje se obično za zupčanike sa modulom većim od $6 \div 7 \mathrm{~mm}$ i prečnikom većim od $300 \mathrm{~mm}$, koji ne mogu biti zagrejani u prstenastom induktoru. Ovakav način kaljenja obezbeđuje zadovoljavajuću izdržljivost na habanje i kontaktnu čvrstoću radnih površina zubaca. Savojna čvrstoća je relativno niska i određena je mehaničkim karakteristikama neokaljenog materijala $u$ zoni opasnog preseka zupca.

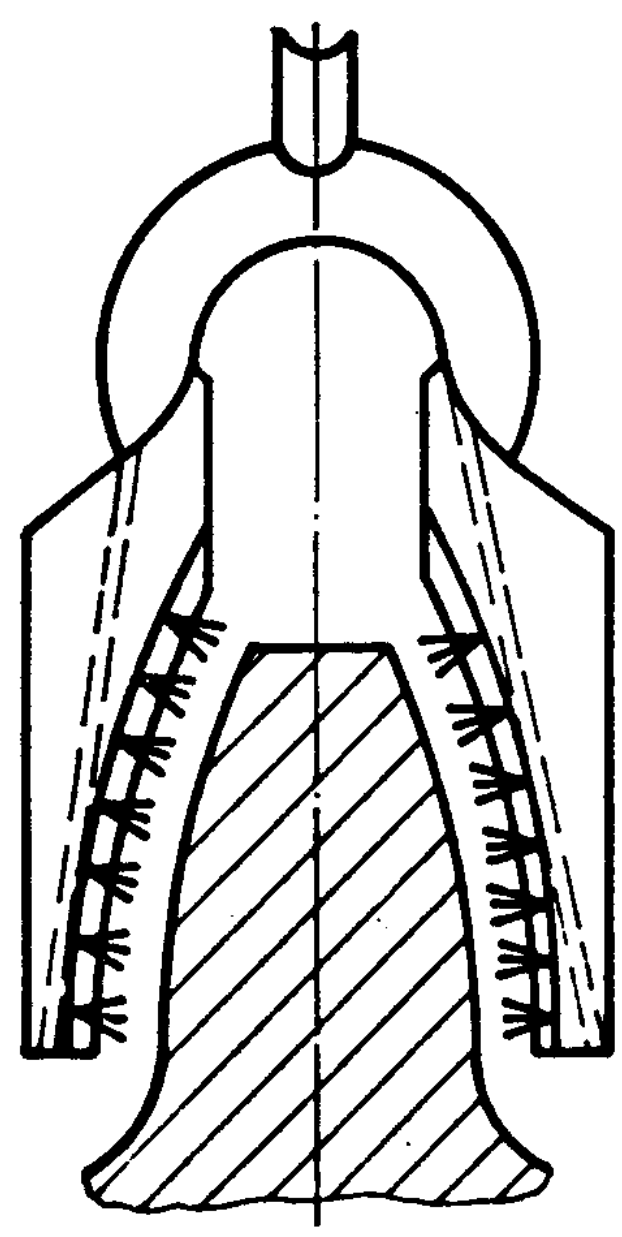

Sl. 18 - Sema indukcionog kaljenja sa konturnim induktorom

Cementacija sa kasnijim kaljenjem primenjuje se za najopterećenije zupčanike. Obezbeđuje visoku čvrstoću (zamornu i udarnu) i otpornost na habanje zubaca. Efekat ojačanja zavisi od tvrdoće i debljine sloja, koncentracije ugljenika i zaostalog austenita, rasporeda karbidnih sastava u sloju, tvrdoce i 
mikrostrukture jezgra. Temperatura cementacije je $920 \div 950^{\circ} \mathrm{C}$. Površinska tvrdoća zubaca posle cementacije, kaljenja i otpuštanja nalazi se u granicama HRC $56 \div 62$. Dobijanju većih vrednosti teži se radi maksimalne otpornosti na habanje (pri odsustvu velikih dinamičkih preopterećenja), a manjih - radi dostizanja maksimalne zamorne i udarne čvrstoće (pri savijanju). Debljina cementacionog sloja kreće se u granicama od 0,4 do $1,8 \mathrm{~mm}$. Koncentracija ugljenika u površinskom sloju je $0,8 \div$ $\div 1,1 \%$. Dobijanju kvalitetnog cementacionog sloja doprinosi korišćenje čelika koji sadrže, molibden i vanadijum, koji povećavaju prokaljivost, nisu skloni zasićivanju sloja ugljenikom i povećanju zaostalog austenita u njemu. Mikrostruktura površinskog sloja, za dobijanje optimalne čvrstoće zubaca, mora biti sitnozrnasta, jednorodna i da ne sadrži grube karbidne mrežice. Raspored zona ojačanja prikazan je na slici 19.

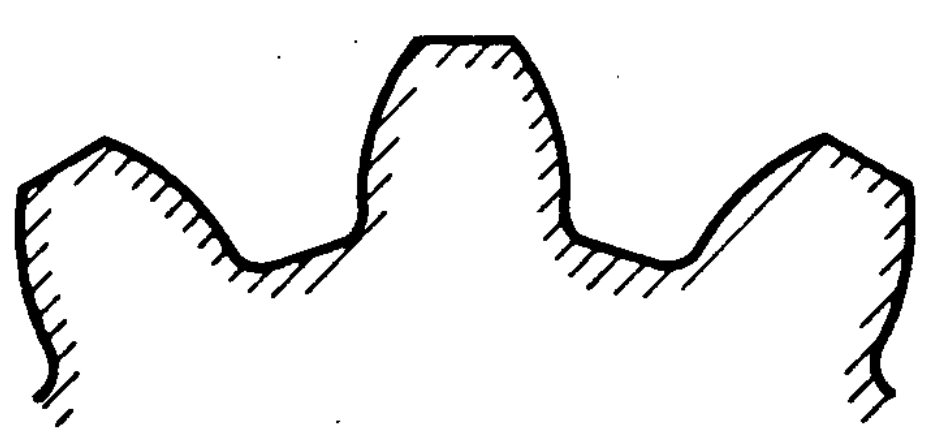

Sl. 19 - Raspored zona ojačanja pri hemijsko-termickoj obradi (cementacija, nitrocementacija, nitriranje)

Tvrdoća jezgra zupca obično se nalazi u granicama HRC $30 \div 40$ za zupčanike sa $\mathrm{m}=2 \div 6 \mathrm{~mm}$ i HRC $27 \div 35$ za veće zupčanike. Za dobijanje optimalne tvrdoće jezgra pri cementaciji zupčanika sa većim modulom primenjuju se čelici sa većim sadržajem ugljenika $(0,25 \%)$ i legirajućih elemenata, koji povećavaju prokaljivost.

Nitriranje se primenjuje radi ojačavanja zupčanika, prvenstveno kada je neophodno izbeći brušenje zubaca (zupčanici složene konfiguracije, sa unutrašnjim ozubljenjem, tankim obodom i sl.).
Istovremeno obezbeđuje neophodnu tačnost, a takođe i maksimalnu otpornost na habanje radnih površina zubaca. Nitriranje obezbeđuje visoku otpornost na habanje, što je vezano za stvaranje submikroskopskih čestica - nitrita u površinskom sloju, a takođe i zadovoljavajuću zamornu čvrstoću zubaca. Nedostatak procesa je njegova dužina i povećana osetljivost nitriranih zupčanika na preopterećenja udarnog karaktera usled krtosti sloja. Debljina sloja za zupčanike sa $\mathrm{m} \leqslant 6 \mathrm{~mm}$ je 0,1 modul, a zupčanike sa $\mathrm{m}>6 \mathrm{~mm}$ je $0,5 \div 0,6 \mathrm{~mm}$. Povećanje karakteristika čvrstoće nitriranih zupčanika velikog modula (u vezi sa smanjenjem relativne debljine sloja ojačanja) obezbeđuje se povećanjem tvrdoće jezgra zubaca.

$\mathrm{U}$ mašinskoj industriji je sve rasprostranjeniji proces gasne nitrocementacije zupčanika. On po osnovnim karakteristikama zauzima prelazni položaj između cementacije i nitriranja. Nitrocementirani zupčanici u poređenju sa cementiranim imaju veću otpornost na habanje i kontaktnu čvrstoću zubaca. Međutim, po zamornoj čvrstoći na savijanje, oni, kao po pravilu, zaostaju za cementiranim. Usled relativno malih deformacija pri obradi, nitrocementirani zupčanici u mnogim slučajevima mogu biti izrađeni bez primene brušenja zubaca. Tvrdoća nitrocementiranih površina zupčanika je HRC $57 \div 60$, tvrdoća jezgra zubaca HRC $30 \div 38$ (pri $\mathrm{m}=$ $=2 \div 5 \mathrm{~mm}$ ). Debljina sloja se uzima za nekoliko manja nego pri cementaciji, ali veća nego pri nitriranju $\approx(0,13 \div 0,2)$ $\mathrm{m}$. Temperatura nitrocementacije je 820 $\div 850^{\circ} \mathrm{C}$.

Pored termičkog i hemijsko-termičkog ojačanja, zupčanici se ojačavaju i plastičnim deformisanjem. Jedan od načina je valjanjem međuzublja, čije su radne površine okaljene, profilisanim valjcima. Ovako se povećava granica izdržljivosti za $40 \div 55 \%$. To povećanje objašnjava se ojačanjem materijala zidova noge zupca i međuzublja i stvaranjem visokih zaostalih napona pritiska u toj zoni. 
Ukoliko remontna preduzeća raspolažu mogućnostima, najsvrsishodnije je organizovati masovnu proizvodnju zupčanika metodom vruće plastične deformacije, ili takozvanim vrućim kovanjem. Ovim načinom skraćuje se odvajanje materijala tako što se zupci formiraju na račun istiskivanja materijala iz međuzublja. Za $40 \div 50 \%$ povećava se njihova otpornost na habanje i produktivnost proizvodnje, jer se može istovremeno iskivati $8 \div 10$ zupčanika.

Koliko je značajno ojačanje zupčanika najbolje pokazuju neki podaci do kojih se došlo ispitivanjima:

- zupčanici transportnih mašina, mašina alatki i drugih uređaja, koji rade na savijanje i sa velikim kontaktnim opterećenjima, površinski se kale i zatim obrađuju valjanjem - imaju povećani vek trajanja za $8 \div 12$ puta, moć nošenja im se povećava za 1,5 put.

- pogonski i gonjeni zupčanici, ojačani cementacijom, imaju povećanu otpornost na habanje za $2 \div 10$ puta $i$ povećanje granice izdržljivosti za $2 \div 3$ puta,

- mali pogonski zupčanici zupčastih prenosnika, ojačani nitrocementacijom, imaju povećanu otpornost na habanje za $10 \div 15$ puta i povećanje granice izdržljivosti za $2 \div 4$ puta.
Regeneracija ožlebljenih spojeva

Najčešća eksploataciona oštećenja na ožlebljenim delovima mašinskih elemenata su: zadori, ogrebotine, habanje, prskotine, uvijenost i savijenost. Ovakvim oštećenjima izloženi su vratila i osovine, kao i glavčine elemenata koji se navlače na njih (zupčanici, kaišnici, spojnice i dr.).

Oštećenja žlebova kao što su: uvijenost, savijenost, zadori, ogrebotine i prskotine otkrivaju se vizuelnim metodom. Prskotine se otkrivaju posmatranjem kroz lupu sa uvećanjem uz istovremeno udaranje čekićem. Na mestu gde postoje prskotine nastaje nejasan zvuk. Pored toga, prskotine se mogu otkriti, ukoliko konstrukcija i oblik mašinskog elementa to dozvoljavaju, metodima magnetne ili ultrazvučne defektoskopije ili prosvetljivanjem rendgenskim zracima. Habanje se određuje metodom tehničkog merenja.

Mašinski elementi čiji su ožlebljeni delovi savijeni ili uvijeni se odbacuju. Isto se odnosi i na postojanje velikih prskotina. Mogu se regenerisati samo ograničene, neprolazne prskotine čija je dubina do $15 \%$ prečnika i dužina manja od $10 \%$ dužine ožlebljenog dela. U takvom slučaju prskotina se razdvoji do

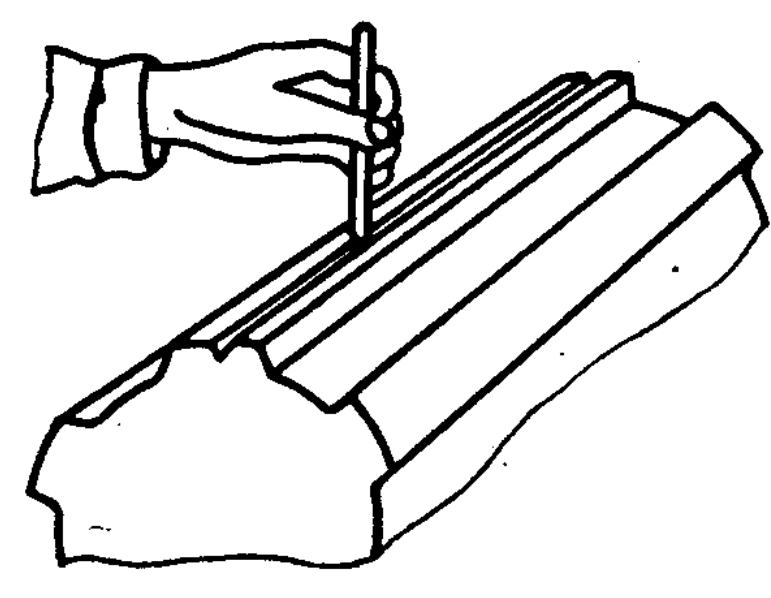

a)
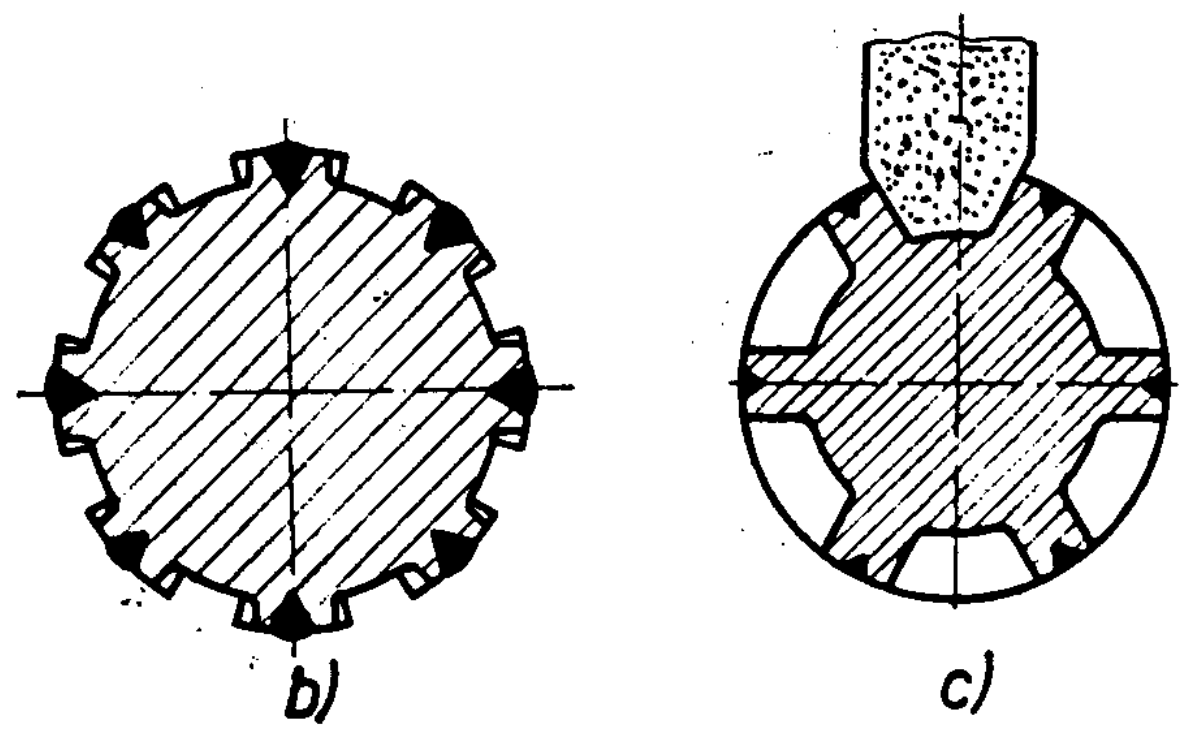

Sl. 20 - Regeneracija ožlebljenog dela vratila metodom razdvajanja 
zdravog materijala, zatim se popuni navarivanjem (najčešće elektrolučnim), pa se otpusti i mehanički obradi.

Pohabanost radnih površina (to jest bočnih površina) ožlebljenih delova mašinskih elemenata najčešće je oštećenje ovih delova. Preciznim mernim instrumentima mere se debljina (širina) žleba i prečnik ožlebljenog dela. Ukoliko su mere manje (odnosno veće) od granično dopuštenih, mašinski element se označava za regeneraciju. Zavisno od eksploatacionih karakteristika i veličine habanja mašinskih elemenata, postoji više načina regeneracije metodom navarivanja.

Pohabani žlebovi se mogu regenerisati pomoću njihovog razdvajanja. Tada se habanje spoljašnje površine kompenzira na račun smanjenja debljine zida. Regeneracija žlebova ovim metodom sastoji se $\mathrm{u}$ tome da se oni otpuštaju, a zatim se po sredini i po celoj dužini razdvajaju. Razdvajanje se vrši pomoću čekića i tupog sekača (slika 20a). Na taj način se bočne strane žleba šire za $1,5 \div 2 \mathrm{~mm}$. Zatim se u stvorene proreze (šliceve) elektrolučno navaruje materijal, koji koriguje i ojačava radne površine žlebova (slika 20b). Na kraju se radne površine žlebova bruse na bruslici za ravno brušenje (slika 20c).
Ukoliko habanje radnih površina žlebova ne prelazi $0,8 \mathrm{~mm}$ i mašinski element se obrće samo u jednom smeru, regeneracija se može izvesti na jednostavniji način. $U$ tom slučaju se na neradne strane žlebova navaruje sloj metala (slika 21a i b). Ožlebljeni deo se koriguje na glodalici na taj način što će na radnim stranama opet biti osnovni materijal, a ne navareni sloj.

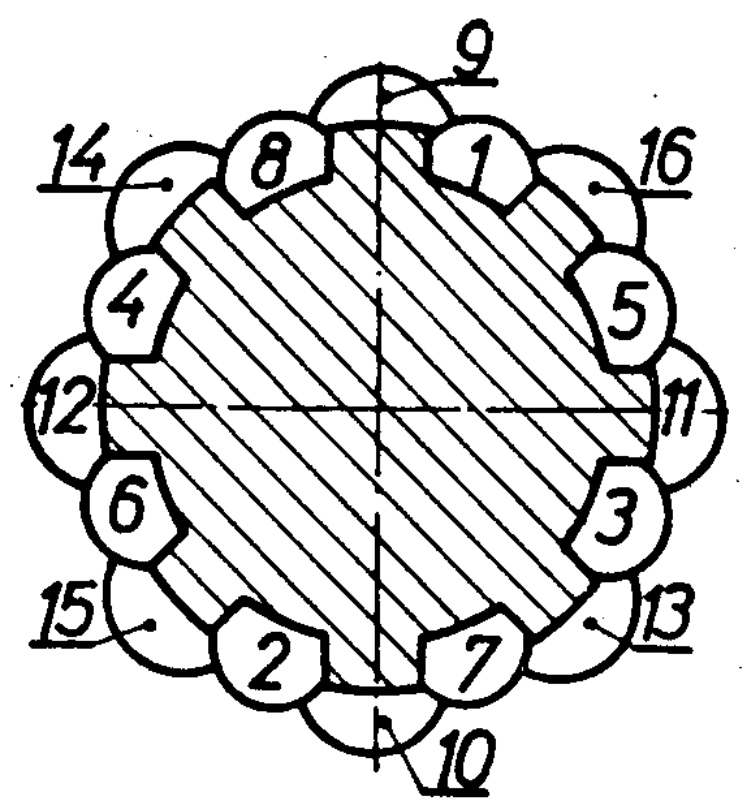

Sl. 22 - Redosled navarivanja u krug veoma oštećenog ožlebljenog dela vratila

Žlebove sa izdrobljenim stranama i prekomernim habanjem najkorisnije je navariti u krug i urezati nove žlebove. Radi sprečavanja deformacija elemen-

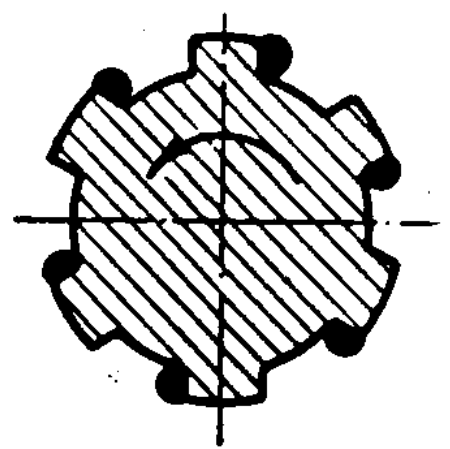

a)

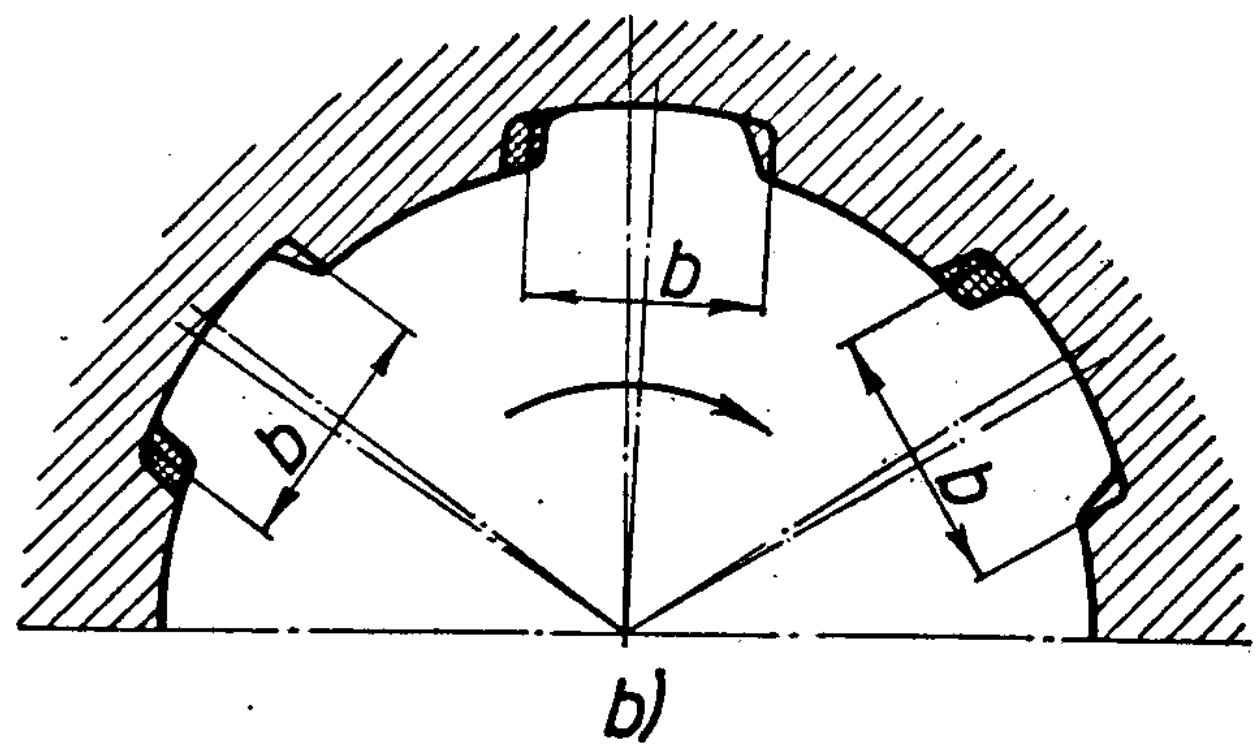

Sl. 21 - Regeneracija pohabanih ožlebljenih delova mašinskih elemenata koji se obrću u jednom smeru:

$a$ - vratila (osovine), $b$ - glavcine 


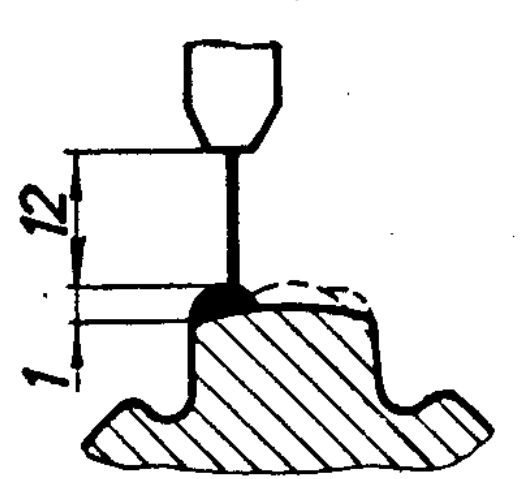

a)

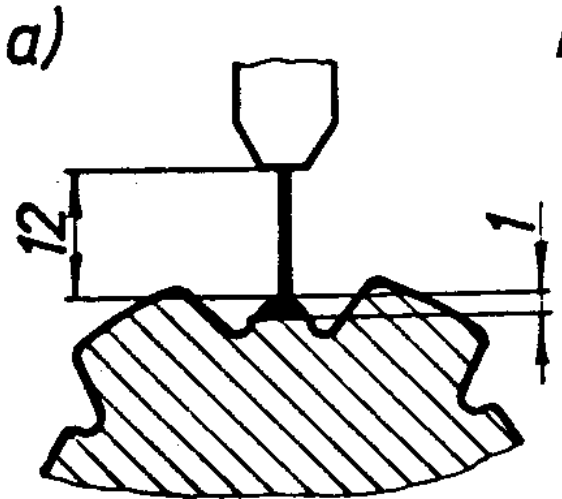

c)

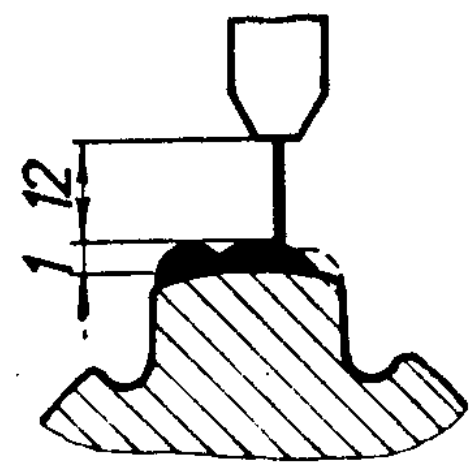

b)

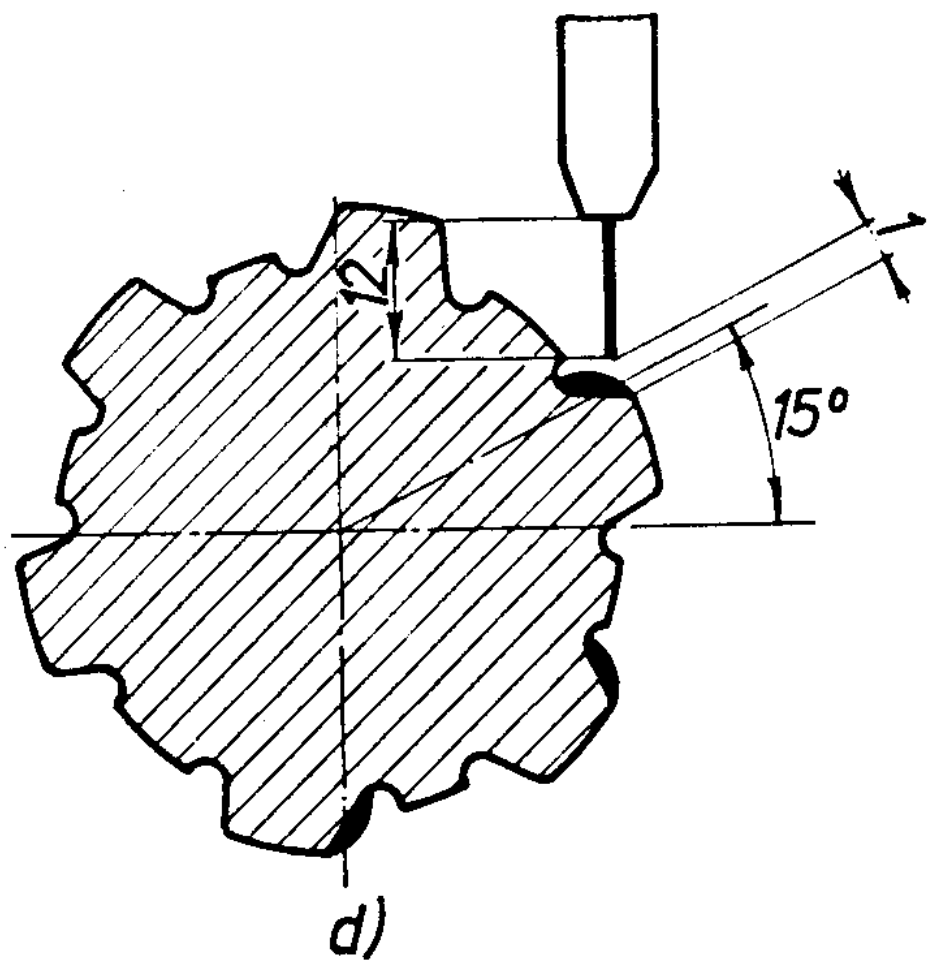

Sl. 23 - Seme navarivanja žlebova i postavljanja elektrode:

a $i b$ - navarivanje spoljne površine žleba, $c$ - navarivanje unutrašnje površine žleba, $d$ - navarivanje bočne površine žleba

ta, navarivanje treba vršiti prema redosledu datom brojevima na slici 22. Navarivanje je elektrolučno, ručno ili automatsko.

U praksi je čest slučaj ožlebljenih delova mašinskih elemenata koji imaju kanale i otvore. Pri regeneraciji takvih elemenata u kanale se uvrću (nabijaju) čelični čepovi, radi izbegavanja deformacija.

Pohabani ožlebljeni delovi vratila regenerišu se ručnim ili automatskim navarivanjem. $\mathrm{Na}$ slici 23 prikazane su šeme navarivanja ožlebljenih delova vratila metodom vibrolučnog navarivanja pod slojem topitelja. Režim navarivanja žicom prečnika $1 \mathrm{~mm}$ je: napon luka $30 \div 32 \mathrm{~V}$, jačina struje $80 \div 85 \mathrm{~A}$, brzina dovođenja žice $138 \mathrm{~m} / \mathrm{h}$.

Tvrdoća navarenog materijala krece se u granicama od HB $370 \div 450$, zavisno od osnovnog materijala, vrste elektrode i topitelja, kvaliteta navarivanja i drugih faktora.

\section{Zaključak}

Regeneracija zupčanika i ožlebljenih mašinskih elemenata zauzima veoma značajno mesto u remontnoj praksi. Ona ima veliku primenu pri remontu elemenata složene konfiguracije, čija je izrada skupa. Primena vrućih metoda regeneracije (navarivanje) znatno je češća od hladnih metoda. Pri izboru metoda regeneracije potrebno je izvršiti analizu pouzdanosti i racionalnosti metoda.

Regeneracijom se moraju povratiti izgubljene geometrijske mere $i$ oblici, kvaliteti površina i druge eksploatacione karakteristike oštećenih zupčastih i ožlebljenih sprega. Istovremeno, mora se voditi računa o rentabilnosti izabranog postupka regeneracije. Sve to daje prednost regeneraciji zupčanika i ožlebljenih delova mašinskih elemenata navarivanjem, sa kasnijom mehaničkom i termičkom obradom.

Da bi se povratile mehaničke karakteristike regenerisanih elemenata, često se vrši njihova termička ili hemijsko-termička obrada. 
Regeneracija zupčanika i ožlebljenih mašinskih elemenata, kao i drugih delova TMS ima izuzetan značaj u kriznim i ratnim uslovima, kada je proizvodnja novih delova otežana ili onemogućena. U takvim uslovima regeneracija može biti jedini izvor snabdevanja

Literatura:

[1] Adam J. I., Ovumjan, G. G. Spravočnik zuboreza, Mašinostrojenije๔, Moskva, 1964.

[2] Arhangorodskij L. A., Tartakovskij M. A., Jacevič V. A.: Remont i montaž oborudovanija predprijatij po hraneniju i prerabotke zerna, -Kolos«, Moskva, 1967.

[3] Ašeko S. M., Klauz P. L., Sokolov K. A.: Remont stroiteljnih, putevih i pogruzocno-razgruzočnih mašin, »Transport๔, Moskva, 1967.

[4] Banatov P. S.: Iznos i povišenije dolgovečnosti gornih mašin, „Nedrak, Moskva, 1970.

[5] Veriga S.: Mašinski elementi III, Mašinski fakultet, Beograd, 1984.

[6] Vitas D. J., Trbojević M. D.: Mašinski elementỉ III Naučna knjigax, Beograd, 1981.

[7] Elizavetín M. A.: Povišenije nadežnosti mašin, Mašinostrojenijek, Moskva, 1973.

[8] Elizavetin M. A., Satelj E. A.: Tehnologiceskije sposobi povišenija dolgovečnosti mašin, "Mašinostrojenije๔, Moskva, 1969.

[9] Ivanov M. N.: Detalji mašin, \Viš̆aja క̌kolak, Moskva, 1967.

[10] Iosilevič G. B.: Detalji mašin, »Mašinostrojenijex, Moskva, 1988. rezervnim delovima i jedina mogućnost da se oštećena i neispravna TMS osposobe.

Zbog toga se izučavanju regeneracije i njenoj primeni mora posvetiti odgovarajuća pažnja.

[11] Koh P. I.: Remont eskavatorov, „Nedrac, Moskva, 1967.

[12] Kuzmin R. V.: Defektacija sudovih mehanizmov, »Transportk, Moskva, 1967.

[13] Kuklin N. G., Kuklina, G. S.: Detalji mašin, „Visšaja škola๔, Moskva, 1987.

[14] Nantev G. G.: Tehničeskoe obsluživanije 1 remont avtomobiljnih kranov, oTransportк, Moskva, 1966.

[15] Pinegin S. V.: Kontaktnaja pročnost i soprotivljenije kaceniju, •Mašinostrojenijeк, Moskva, 1969.

[16] Proizvodstvo zubcatih koles (spravocnik), »Mašinostrojenije«, Moskva, 1990.

[17] Rešetov D. N.: Detalji mašin, "Mašinostrojenijex, Moskva, 1989.

[18] Savić Z.: Mašinski elementi, Mašinski fakultet, Beograd, 1974.

[19] Tanasijević S.: Osnovi tribologije mašinskih elemenata, „Naučna knjlgak, Beograd, 1989.

[20] Forrest P. G.: Fatigue of metals, Pergamon press, Oxford - London - New York - Paris, 1962. 